\title{
The role of p53 in cancer drug resistance and targeted chemotherapy
}

\author{
Karin Hientz ${ }^{1}$, André Mohr ${ }^{1}$, Dipita Bhakta-Guha ${ }^{2}$ and Thomas Efferth ${ }^{1}$ \\ ${ }^{1}$ Department of Pharmaceutical Biology, Institute of Pharmacy and Biochemistry, Johannes Gutenberg University, Mainz, \\ Germany \\ ${ }^{2}$ School of Chemical and Bio Technology, SASTRA University, Tamil Nadu, India \\ Correspondence to: Thomas Efferth, email: efferth@uni-mainz.de \\ Keywords: cytotoxic chemotherapy, drug resistance, medicinal chemistry, prognostic factors, targeted chemotherapy \\ Received: July 10, $2016 \quad$ Accepted: October 13, $2016 \quad$ Published: November 19, 2016
}

\section{ABSTRACT}

Cancer has long been a grievous disease complicated by innumerable players aggravating its cure. Many clinical studies demonstrated the prognostic relevance of the tumor suppressor protein p53 for many human tumor types. Overexpression of mutated p53 with reduced or abolished function is often connected to resistance to standard medications, including cisplatin, alkylating agents (temozolomide), anthracyclines, (doxorubicin), antimetabolites (gemcitabine), antiestrogenes (tamoxifen) and EGFR-inhibitors (cetuximab). Such mutations in the TP53 gene are often accompanied by changes in the conformation of the p53 protein. Small molecules that restore the wild-type conformation of p53 and, consequently, rebuild its proper function have been identified. These promising agents include PRIMA-1, MIRA-1, and several derivatives of the thiosemicarbazone family. In addition to mutations in p53 itself, p53 activity may be also be impaired due to alterations in p53's regulating proteins such as MDM2. MDM2 functions as primary cellular p53 inhibitor and deregulation of the MDM2/p53-balance has serious consequences. MDM2 alterations often result in its overexpression and therefore promote inhibition of p53 activity. To deal with this problem, a judicious approach is to employ MDM2 inhibitors. Several promising MDM2 inhibitors have been described such as nutlins, benzodiazepinediones or spiro-oxindoles as well as novel compound classes such as xanthone derivatives and trisubstituted aminothiophenes. Furthermore, even naturally derived inhibitor compounds such as a-mangostin, gambogic acid and siladenoserinols have been discovered. In this review, we discuss in detail such small molecules that play a pertinent role in affecting the p53-MDM2 signaling axis and analyze their potential as cancer chemotherapeutics.

\section{INTRODUCTION}

p53 unfurled

TP53 (tumor suppressor gene p53) is one of the most well-studied tumor suppressor genes. Because of its pivotal role in protecting from malignancies, p53 is called "guardian of the genome" [1-4]. Its signaling is triggered through myriad cellular events ranging from DNA damage to hypoxia, stress and a plethora of other causes [2, 3, 5-7]. Upon activation, p53 acts as zinc-containing transcription factor [7-11] and regulates downstream genes that are involved in DNA repair, cell cycle arrest or apoptosis $[6,7,12-15]$. Apoptosis is initiated by trans-activating pro-apoptotic proteins such as PUMA (p53 upregulated modulator of apoptosis) $[15,16]$, FAS (cell surface death receptor) $[2,15]$, or BAX (Bcl-2-associated X protein) [2, $6,7,15-17]$. In contrast, cell cycle arrest is induced by $\mathrm{p} 53$ via trans-activating genes such as p21 (CDK-inhibitor 1 , cyclin dependent kinase) $[2,6,7,15]$ and others $[3,15]$. Interestingly, p53 itself is capable of triggering cellular responses (survival or induced cell death) as well. This ability may vary according to the cell type, intensity of stress signal and/or extent of cellular damage [15]. Besides an augmentation of the protein level, the activation of 
p53 also includes post-translational modifications in the protein itself, which subsequently activates $\mathrm{p} 53$-targeted genes [18]. One such post-translational modification is induced by DNA damage. Similar damage leads to activation of kinases like ATM (Ataxia telangiectasiamutated protein) $[3,4,17,18]$ and Chk2 (Checkpoint kinase 2), which subsequently phosphorylate p53, resulting in p53-dependent cell cycle arrest or apoptosis [18]. In normal cells, expression of p53 is low $[7,13]$ and its half-life is about $20 \mathrm{~min}$ [13]. However, in the case of cellular stress, p53's half-life is extended to several hours, which consequentially results in elevated $\mathrm{p} 53$ protein levels in the cell [18]. As cellular gatekeeper [7, 12, 18, 19], a primary role of p53 is to recognize, whether damage is irrevocable and accordingly induce apoptosis $[18,19]$.

\section{The involvement of p53 in cancer}

It is well known that p53 suppresses tumor formation and renders protection against DNA damage by inducing cell cycle arrest, DNA repair, or apoptosis $[2,6$, $7,20,21]$. However, the p53 pathway is often mutated in cancer [12]. In fact, mutations or deletions in the TP53 gene are present in nearly $50 \%$ of human cancers, and primarily results in impaired tumor suppressor function [22]. Upon loss of p53 functionality, damaged cells may proliferate transferring mutations to the next generation [20]. It is through this mechanism that deregulation of p53 often leads to the formation of tumors [20].

Cancers harboring mut-p53 (mutant p53) are commonly characterized by aggravated metastasis and genomic instability [23, 24]. Several in vitro studies have exhibited additional oncogenic functions of mut-p53 in addition to tumor suppression. These functions include promoting invasion, migration, angiogenesis and proliferation [23]. To worsen the matter further, mut-p53 is also responsible for enhanced drug resistance and mitogenic defects [23]. The above functions are just a few of the plethora of characteristics attributed to p53. This suggests the presence of multiple pathways, through which p53 asserts a crucial role in cancer progression that are impacted by mut-p53 [23].

Mutations in p53 may arise due to an anomaly in the position of any amino acid [23]. However, multiple reports indicate preferred sites of mutation: R175, G245, R248, R249, R273, and R282 [23]. Mut-p53 can be broadly classified into structural and DNA-contact mutants. While the former causes unfolding of wild-type p53 (wt p53) protein, the latter changes single amino acids, disabling the binding of $\mathrm{p} 53$ to DNA (53). The conglomeration of mutations indicates that the DNA-binding activity of p53 is the main critical function, which is commonly modified in p53 mutants $[23,25]$. It is interesting to note that the majority of mutations occur in the core domain of $\mathrm{p} 53$, which usually harbors sequence-specific DNA binding activity (residues 102-292) [26]. Consequently, mutations in this site result in the loss of DNA binding.

Muller and Vousden have described four different mechanisms of mut-p53 [23]. These mechanisms stand testimony to the changes in the interaction between mut-p53 and other proteins. Among these proteins, transcription factors play a crucial role. In model 1, mut-p53 interacts with DNA by using mut-p53 binding elements or directly interacts with other parts of the DNA. In model 2 and 3, mut-p53 binds to transcription factors or other proteins and selectively enhances (e.g. NF-Y, nuclear factor Y) or inhibits (e.g. p63) their functions. Proteins that are not directly associated to the regulation of gene expression (e.g. NRD1, nardilysin 1) can also be enhanced or blocked by mut-p53 (model 4). Alteration in DNA-binding ability is yet another important mechanism through which mut-p53 has been observed to function [23]. Thus the manifold contributions of p53 to disease progression makes exploring its role in pathogenesis indispensable.

\section{MDM2 antagonizes p53}

Despite the significant role of mut-p53 in cancer pathobiology, the intriguing fact remains that half of all cancer patients carry wt p53 [27]. This indicates the existence of other factors that favor tumor formation and progression. One such factor is the p53-inhibitory protein MDM2 (murine double minute 2). MDM2 is the key physiological regulator of p53 and tightly controls p53 protein levels [12] (Figure 1). It contains a RING (really interesting gene) domain at the $\mathrm{C}$ terminus functioning as an E3 ligase along with a p53-binding domain at the $\mathrm{N}$ terminus [16]. Wild-type $\mathrm{p} 53$ acts as transcription factor, activating MDM2 to target $\mathrm{p} 53$ for degradation [7, 9-11, 28]. p53 binds to the MDM2 promoter, thereby increasing MDM2 expression [22]. While on the one hand MDM2 binds to p53 and blocks its N-terminal transactivation domain, it induces p53's degradation via ubiquitin-proteasome machinery on the other hand [12]. After cellular stress such as DNA damage, MDM2's activity decreases leading to p53 stabilization [11, 2830]. The resulting increase in $\mathrm{p} 53$ protein levels leads to an upregulation of MDM2 activity, which in turn causes degradation of p53 [10, 28, 31]. Thus, the cellular levels of p53 and its inhibitor MDM2 are in turn, mutually controlled by negative feedback loop [9-11, 28, 30], wherein MDM2 downregulates p53 and p53 upregulates MDM2. As a result of this regulatory circuit, the nuclear concentrations of both $\mathrm{p} 53$ and MDM2 are normally kept at low levels [12]. Therefore, a deregulated MDM2/p53 balance, (e.g. by overexpression of MDM2) may have devastating consequences [22].

Such imbalance is often associated with malignant changes in normal cells. Increased MDM2 levels lead to tumorigenesis and correlate with poor clinical prognosis [22]. The overall frequency of $M D M 2$ gene amplification 
in human tumors is around $7 \%$. In a study comprising approximately 4000 biopsies obtained from clinical or xenograft tumors across 28 tumor types, the frequency of MDM2 amplifications varied over a wide range in different types of cancer. The highest frequency of $M D M 2$ amplification was observed in soft tissue tumors $(20 \%)$, and osteosarcomas followed second with an incidence of $16 \%$ [32]. Several mechanisms have been suggested for MDM2 overexpression. In addition to gene amplification, a specific single nucleotide polymorphism (SNP) in the MDM2 gene promoter (SNP309) leads to enhanced transcription and increased translation $[22,33]$. Therefore, the interaction between MDM2 and p53 suggests an appealing strategy for treatment of cancer and represents a promising therapeutic target [16].

\section{RESISTANCE TO STANDARD MEDICATION}

The relationship between a target and a drug does not stand alone. Any drug-target interaction is plagued with many other factors that pose threats to the holistic therapeutic strategy. One such factor is drug resistance. Resistance towards cytotoxic drugs still presents an enormous problem in the treatment of cancer [34]. Some mechanisms of drug resistance have been recently classified by Marin et al. The authors distinguished between different classes of mechanisms: those involving drug uptake or export, mechanisms concerning metabolic prodrug activation or drug inactivation, changes in molecular targets, as well as mechanisms regarding DNA repair or modifications in the pro- and antiapoptotic balance [151]. Table 1 gives an overview of mechanisms of drug resistance.
Mutations in the p53 gene are modifications in the proapoptotic balance causing drug resistance (Table 2). Alterations in p53 frequently occur in tumors and result in loss of p53 function [35]. The correlation between p53 mutation status and sensitivity to cytotoxic drugs has been confirmed by a large study conducted by the National Cancer Institute, USA, where 60 cell lines and more than 100 anticancer drugs were examined [36]. However, the way in which p53 influences drug resistance depends on several different parameters including the mode of action of the drug, genetic alterations during carcinogenesis, and the type of cancer [35]. A comprehensive overview of mechanisms of resistance development against all cytotoxic drugs is beyond the scope of a single review article. We therefore have selected several chemotherapeutic agents and described their mechanisms of drug resistance in Table 2.

\section{AGENTS RESTORING P53 WILD-TYPE CONFORMATION}

Missense mutations in TP53 often result in the accumulation of mutant and misfolded proteins in the nucleus [66]. Re-folding of this mutated and accumulated p53 leads to restoration and activation of defective proteins, resulting in high levels of active p53, which then induces apoptosis [67]. Therefore, small molecules capable of restoring p53 function, pose an attractive new class of anticancer drugs (Figure 2).

In the past years, several mut-p53-reactivating compounds have been described. An overview is given in Table 3.

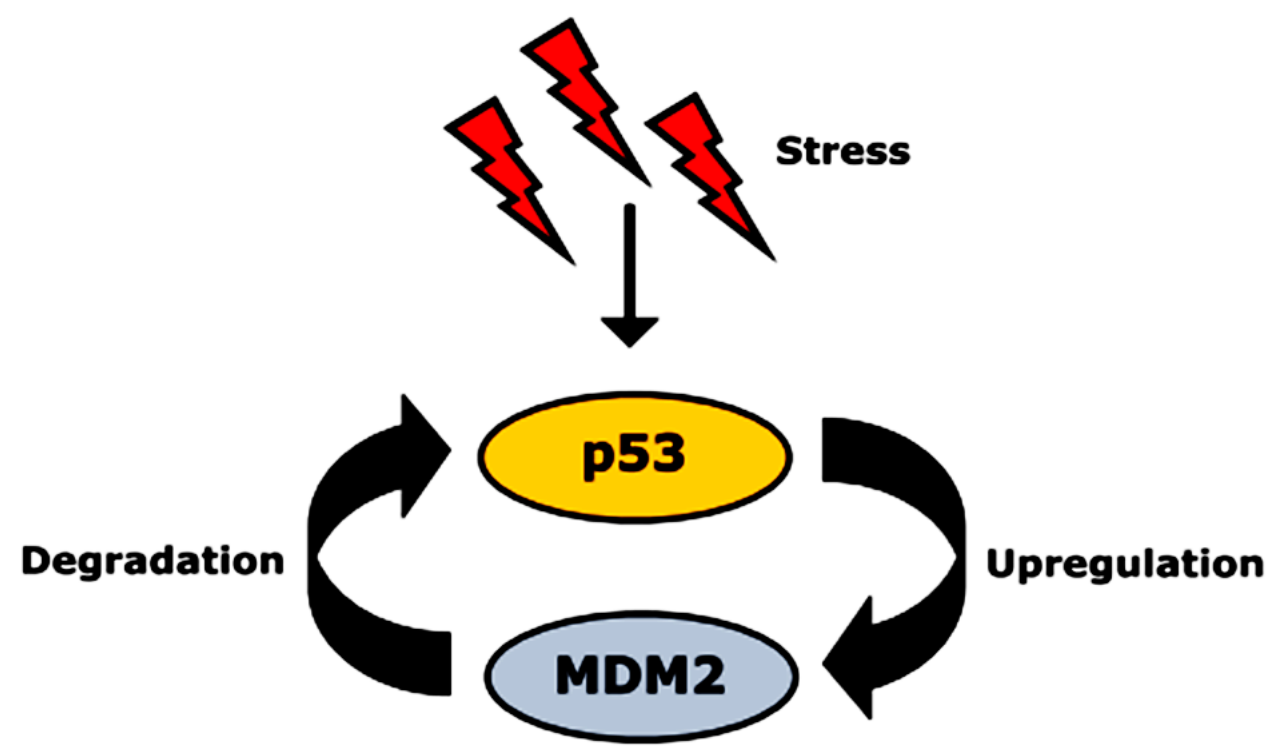

Figure 1: Autoregulatory feedback loop between p53 and its negative regulator, MDM2. After activation due to stress signals, p53 upregulates MDM2 gene expression and increases MDM2 protein levels. As negative regulator, MDM2 protein then binds to p53 and induces its degradation [22]. 
Table 1: General mechanisms of drug resistance classified in groups [35]

\begin{tabular}{|c|c|c|}
\hline $\begin{array}{l}\text { Mechanism of } \\
\text { Chemoresistance }\end{array}$ & & Reference \\
\hline Drug Uptake & $\begin{array}{l}\text { Transporters of the superfamily of solute carriers (SLCs) play an important role } \\
\text { in the uptake of cytotoxic drugs. If changes occur in the expression of these } \\
\text { transporters, tumor cells are less able to take up anticancer drugs leading to the } \\
\text { development of resistance. }\end{array}$ & {$[36,37]$} \\
\hline Drug Export & $\begin{array}{l}\text { Overexpression of members of the superfamily of ATP-binding cassette (ABC) } \\
\text { proteins represents another major problem in resistance to chemotherapy. MDR1 } \\
\text { (multidrug resistance protein 1, ABCB1 gene) is one of such ABC protein. It acts } \\
\text { by bumping out potentially toxic compounds and is therefore also limiting the } \\
\text { intracellular concentration of cytotoxic drugs. }\end{array}$ & {$[35,38]$} \\
\hline $\begin{array}{l}\text { Metabolic Prodrug } \\
\text { Activation or Drug } \\
\text { Inactivation }\end{array}$ & $\begin{array}{l}\text { Changes affecting the drug metabolism are another reason for resistance. Tumor } \\
\text { cells overexpressing detoxifying phase I and phase II enzymes possess an } \\
\text { enhanced ability to inactivate cytotoxic drugs. An increased CYP3A4 activity, } \\
\text { an enzyme of the cytochrome P450 family, inactivates for example paclitaxel in } \\
\text { colorectal cancer cells. Furthermore, even a reduced expression of drug activators } \\
\text { led to reduced drug sensitivity. For example carboxylesterases, normally involved } \\
\text { in intracellular activation of irinotecan, are reduced in cancer cells with enhanced } \\
\text { resistance to irinotecan. }\end{array}$ & {$[35,39],[40]$} \\
\hline $\begin{array}{l}\text { Changes in } \\
\text { Molecular Targets }\end{array}$ & $\begin{array}{l}\text { Changes in molecular targets and defective signaling pathways are altering } \\
\text { the sensitivity of tumor cells to anticancer drugs. For example, the mechanism } \\
\text { of action of anthracyclines is based on their ability to interact with DNA } \\
\text { topoisomerases. Mutations in the TOP1 gene, encoding topoisomerase } 1 \text { led to a } \\
\text { reduced ability of anthracyclines to interact with their target. }\end{array}$ & {$[35]$} \\
\hline DNA Repair & $\begin{array}{l}\text { The enhanced ability of tumors cells to repair drug-induced DNA damages leads } \\
\text { to resistance. Nucleotide excision repair is one major DNA mechanism, resulting } \\
\text { from the use of alkylating agents. Furthermore, mismatch repair (MMR) is } \\
\text { involved in the correction of erroneously matched nucleotides. The loss of MMR } \\
\text { activity causes genetic instability with enhanced resistance to a large variety of } \\
\text { anticancer drugs. }\end{array}$ & {$[35,41,42]$} \\
\hline $\begin{array}{l}\text { Modifications } \\
\text { in the Pro- and } \\
\text { Antiapoptotic } \\
\text { Balance }\end{array}$ & $\begin{array}{l}\text { Modifications of key factors of apoptosis such as p53 play a major role in } \\
\text { resistance. Also BAX function is often impaired due to mutations in the } B A X \\
\text { gene, leading to the synthesis of truncated proteins and the development of } \\
\text { oxaliplatin-resistant cells. } \\
\text { Furthermore, also the upregulation and abnormal expression of antiapoptotic } \\
\text { factors such as Bcl-2 (B-cell lymphoma protein 2) or Bcl-XL (B-cell lymphoma } \\
\text { protein extra-large) are connected to enhanced resistance. }\end{array}$ & {$[35,43]$} \\
\hline
\end{tabular}

\section{Thiosemicarbazones}

A novel class of compounds that act as re-activators of mut-p53 has been investigated by $\mathrm{Yu}$ and co-workers [8]. Using the compound library of the National Cancer Institute (NCI), USA; they identified three compounds (NSC319725, NSC319726, NSC328784) showing promising inhibitory effects in mut-p53 cell lines [8]. Comparing cell lines with mut-p53 and wt-p53, significantly lower $\mathrm{IC}_{50}$ values have been found in cells with the mutated status. NSC319726 exhibited particularly low $\mathrm{IC}_{50}$ values in cells with a p53 mutation in the 175 allele. Furthermore, the compound was remarkably nontoxic to human fibroblasts (with wt-p53). The authors observed a two-fold higher induction of apoptosis in the $\mathrm{p} 53^{\mathrm{R} 175}$ mutant than in other mutant cell lines. Upon silencing the expression of mutant $\mathrm{p} 53^{\mathrm{R} 175}$ protein, the sensitivity to these compounds was strongly reduced. This led to the conclusion that the activity of NSC319726 was dependent on $\mathrm{p} 53^{\mathrm{R} 175}$ mutant protein [8].
Wt-p53 includes one zinc ion as an important cofactor, which is coordinated to the side chains of three cysteine residues and one histidine residue in the DNAbinding domain. The metal ion stabilizes the second and third loop within the DNA-binding domain and is essential for its correct function. In p53 mutants on the other hand, zinc is recurrently missing [72]. Mutations in any of the zinc-coordinating residues result in the inability of p53 to bind to zinc. Although the R175 mutant is not directly involved in zinc binding, a histidine residue at this location is capable of inducing structural distortions in the protein, thereby preventing binding of zinc [70].

Generally, metal ion chelation changes p53 conformation $[73,74]$. Therefore, NSC319726 treatment induces a wild-type-like conformational change in the p53-mutant protein, because of its metal-ion chelating properties. The R175 mutant p53 fails to bind zinc, but upon treatment with NSC319726 and zinc chloride at low concentrations, zinc binding was detected [70]. Therefore, NSC319726 may serve as source of zinc to allow the p5 $3^{\mathrm{R} 175}$ mutant to refold to its wild-type conformation [70]. 
Table 2: Resistance towards standard medications in mut-p53 harboring cancer cells.

\begin{tabular}{|c|c|c|c|c|}
\hline Agent & Agent Class & $\begin{array}{l}\text { Mechanism of Drug } \\
\text { Action }\end{array}$ & $\begin{array}{l}\text { Possible mechanism of Resistance in } \\
\text { p53 mutant cells }\end{array}$ & Reference \\
\hline Cisplatin & $\begin{array}{l}\text { Platinum-based } \\
\text { complex }\end{array}$ & $\begin{array}{l}\text { Inhibition of DNA } \\
\text { replication by DNA } \\
\text { cross-linking after Cl- } \\
\text { elimination. }\end{array}$ & $\begin{array}{l}\text { Mutant p53 upregulates Nrf2 (nuclear } \\
\text { factor erythroid } 2 \text {-related factor } \\
2 \text {, a transcription factor coding for } \\
\text { detoxification enzymes and conferring } \\
\text { resistance to anticancer drugs) in non- } \\
\text { small cell lung cancer by increased } \\
\text { binding to the Nrf2 promoter supported } \\
\text { by an activation of the NF- } \mathrm{B} \\
\text { signaling pathway leading to additional } \\
\text { enhancement of Nrf2 expression. } \\
\text { Furthermore, loss of DNA mismatch } \\
\text { repair favors cisplatin resistance in p53 } \\
\text { mutant colon carcinoma cells. }\end{array}$ & {$[46-50]$} \\
\hline Temozolomide & Alkylating agent & $\begin{array}{l}\text { DNA damage and } \\
\text { inhibition of cell } \\
\text { division by inserting } \\
\text { alkyl groups in the } \\
\text { DNA. }\end{array}$ & $\begin{array}{l}\text { In temozolomide-resistant glioma cells, } \\
\text { a correlation between mutant TP53 } \\
\text { and MGMT (O6-methylguanine DNA- } \\
\text { methyl-transferase) was observed. } \\
\text { While temozolomide kills cells by } \\
\text { alkylating O6-guanine, MGMT in } \\
\text { turn repairs alkylation. Therefore drug } \\
\text { resistance may be caused by MGMT } \\
\text { up-regulation. }\end{array}$ & {$[15,51-56]$} \\
\hline Doxorubicin & Anthracycline & $\begin{array}{l}\text { Intercalation into DNA } \\
\text { and inhibition of DNA- } \\
\text { topoisomerase II leading } \\
\text { to DNA damage and } \\
\text { apoptosis. }\end{array}$ & $\begin{array}{l}\text { TP53 mutations affecting or disrupting } \\
\text { the zinc atom chelating, L2/L3 DNA } \\
\text { binding domains of the p53 protein } \\
\text { are linked to primary resistance to } \\
\text { doxorubicin therapy in breast cancer. } \\
\text { Furthermore polymorphism in codon } \\
72 \text { (Arg/Pro) of p53 affects cellular } \\
\text { sensitivity to anticancer drugs such as } \\
\text { doxorubicin through inhibition of p } 73 \text {, } \\
\text { a protein related to p53. }\end{array}$ & {$[57-62]$} \\
\hline Gemcitabine & Antimetabolite & $\begin{array}{l}\text { Interference of normal } \\
\text { metabolism due to } \\
\text { the masquerade of } \\
\text { antimetabolites as a } \\
\text { natural metabolic } \\
\text { element. This inhibits } \\
\text { normal cell development } \\
\text { and cell division. }\end{array}$ & $\begin{array}{l}\text { Gemcitabine treatment stabilizes } \\
\text { mutant p53 in the nuclei and induces } \\
\text { the expression of mutant p53 target } \\
\text { genes CdK1 (cyclin-dependent kinase } \\
\text { 1) and CCNB1 (G2/mitotic-specific } \\
\text { cyclin-B1), which are both involved in } \\
\text { mitosis and therefore cell proliferation, } \\
\text { leading to gemcitabine resistance in } \\
\text { pancreatic cancer cells. }\end{array}$ & {$[63-65]$} \\
\hline Tamoxifen & $\begin{array}{l}\text { SERM (selective } \\
\text { estrogen receptor } \\
\text { modulator) }\end{array}$ & $\begin{array}{lrr}\begin{array}{l}\text { Suppression } \\
\text { (estrogen }\end{array} \text { receptor)- } \\
\text { mediated } \\
\text { expression and cell } \\
\text { proliferation due to } \\
\text { antagonizing } \\
\text { Especially, ERs. } \\
\text { can exert both agonistic } \\
\text { and antagonistic activity } \\
\text { depending on the target } \\
\text { tissue and can therefore } \\
\text { be considered as SERM. }\end{array}$ & $\begin{array}{l}\text { Expression of ER and p53 is mutually } \\
\text { regulated through a feedback } \\
\text { loop. While ER upregulates p53 } \\
\text { expression by protein stabilization } \\
\text { and transcriptional regulation, p53 } \\
\text { upregulates ER again. That may explain } \\
\text { why mutations in p53 would inhibit ER } \\
\text { expression, decreasing the effects of } \\
\text { tamoxifen in breast cancer and leading } \\
\text { to drug resistance. }\end{array}$ & {$[66-71]$} \\
\hline Cetuximab & $\begin{array}{l}\text { EGFR (epidermal } \\
\text { growth ractor } \\
\text { receptor) }\end{array}$ & $\begin{array}{l}\text { Monoclonal antibodies } \\
\text { block epidermal } \\
\text { growth factor receptor } \\
\text { (EGFR), inhibiting } \\
\text { signal transduction and } \\
\text { therefore leading to } \\
\text { reduced tumor growth. }\end{array}$ & $\begin{array}{l}\text { Mutant p53 influences ERK } \\
\text { (extracellular-signal regulated } \\
\text { kinases) pathway and ERK-mediated } \\
\text { transcription of Egr-1 (early growth } \\
\text { response-1), which in turn increases } \\
\text { the secretion of EGFR ligands, causing } \\
\text { stimulation of EGFR signaling and } \\
\text { therefore making EGFR-inhibitor } \\
\text { treatment ineffective. }\end{array}$ & {$[72-74]$} \\
\hline
\end{tabular}


Table 3: Overview of agents reactivating mut-p53.

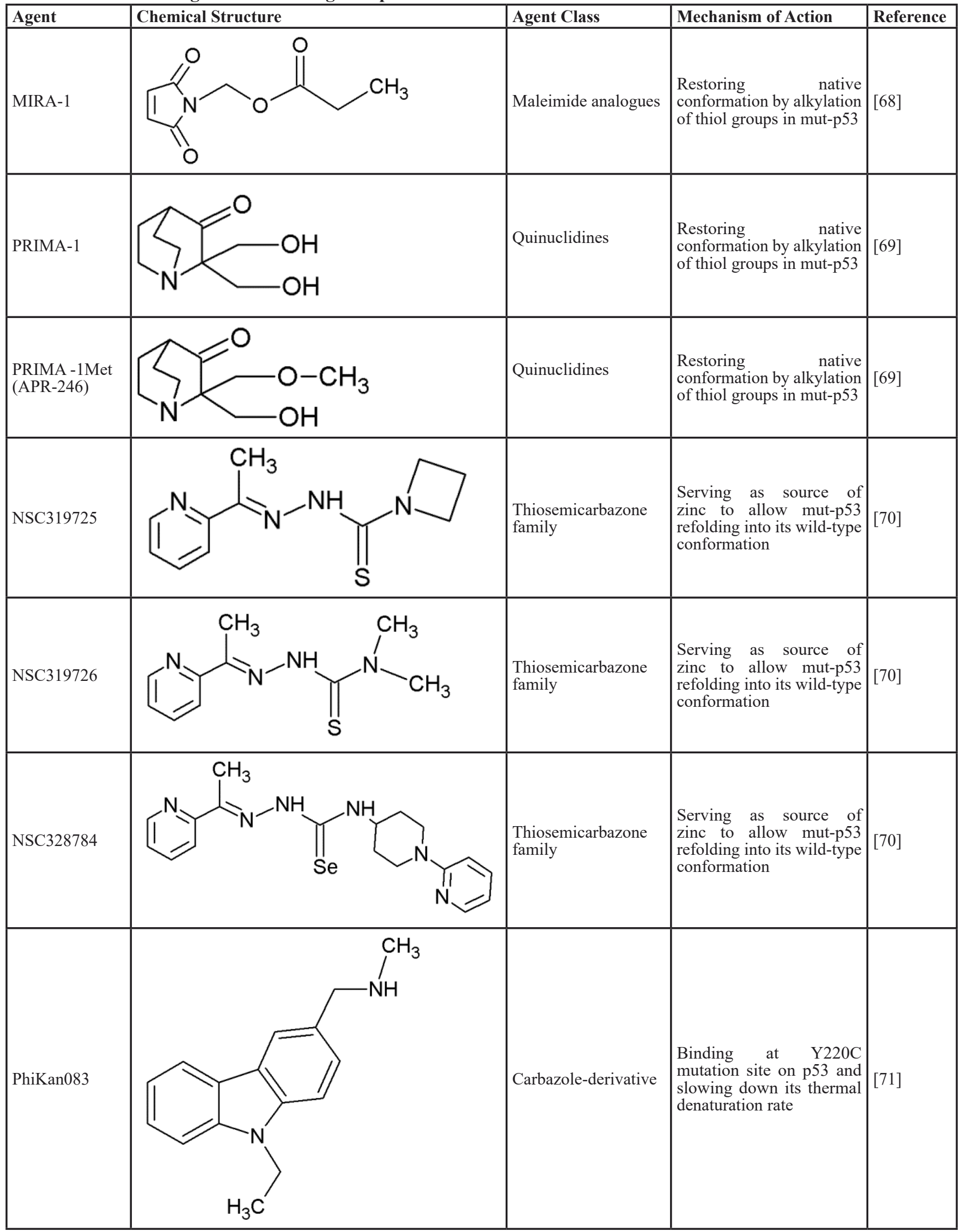


NSC319726 may be a promising compound for three reasons: firstly, because $\mathrm{p} 53^{\mathrm{R} 175}$ mutant reactivation has been observed in vivo at doses that are non-toxic to human tissues harboring wt-p53. Secondly, the compound exhibited a wide therapeutic window. Thirdly, the target, mut-p53 protein, is frequently found in tumor cells. According to the International Agency for Research on Cancer (IARC) TP53 database, the 175 mutant is the third most commonly found missense mutation in TP53 [70, $75]$.

\section{PhiKan083}

Rauf et al. presented another small molecule mut-p53 reactivator, PhiKan083 [72]. It is a carbazolederivative, which binds at the Y220C mutation site on p53 and slows down its thermal denaturation rate [71]. Y220C is one of the most frequent mutations in cancer $[76,77]$ and is located outside the DNA-binding surface of p53. In this mutation, the replacement of a tyrosine by a cysteine leads to decreased thermodynamic stability [72]. Although the mutation does not change the overall structure of the protein [78], several electrostatic interactions are lost. More precisely, the S7/S8 loop of the protein is destabilized, because Tyr220 cannot build electrostatic interactions with the residues Val147, Pro151, Pro153 and Pro223. This leads to the displacement of the loop from its original position [72]

A drugable cavity is created on the surface at the mutation site, which is far from the functional region of p53. PhiKan083 occupies this cavity and is involved in electrostatic interactions with Pro155, Glu221 and Thr230 as well as hydrogen bonds with Leu145 and Asp228. These interactions stabilize the S7/S8 loop and prevent its displacement. As a result of loop stabilization, PhiKan083 raises the melting temperature of Y220C mutant p53 and consequently decreases thermal denaturation [79].

\section{PRIMA-1 and PRIMA-1Met}

Another compound that represents a breakthrough in the reactivation of p53 is p53-Reactivation and Induction of Massive Apoptosis-1 (PRIMA-1), which was identified by Wiman and colleagues [79]. This quinuclidine compound rescued the DNA-binding activity in vitro in numerous mut-p53 protein species [66]. Its methylated analogue PRIMA-1 ${ }^{\text {Met }}$ (also known as APR246) showed even greater potential [67].

Treatment with quinuclidines upregulated p53 target genes such as BAX, PUMA and NOXA [79]. Furthermore, PRIMA-1 and APR-246 induced activation of caspases -2, -3 and -9 [8]. Under physiological conditions, PRIMA-1 and APR-246 are rapidly converted into a reactive intermediate compound, MQ (methylene quinuclidinone). MQ acts as Michael acceptor and covalently binds to the core domain of p53 [80]. Conversion of PRIMA-1 and APR-246 to MQ renders them biologically active. As expected, derivatives that cannot be transformed into this reactive form are biologically inactive. Therefore, PRIMA-1 and APR-246 can be considered as prodrugs, which need to be activated in vivo [79]. However, due to its limited stability at physiological conditions, MQ itself cannot be used as a mut-p53-targeting compound and thus necessitates further improvement [80].

Due to incorrect folding, mut-p53 proteins may expose cysteine residues, which are hidden in the core domain of wt-p53 [79]. This can lead to the formation of inter- and intramolecular disulfide bonds, locking mut-p53 in an inactive conformation and causing protein aggregation. Thiol modification by reactive compounds such as MQ prevented the formation of such disulfide bonds and thus promoted correct folding and restoration of the wild-type function [8].

However, it is not clear which of the 10 cysteine residues in the p53 core domain are modified by MQ. Cys182, Cys229, Cys242 and Cys277 are all exposed on the surface of the core domain, and are potential targets for modifications $[64,81]$. According to Lambert

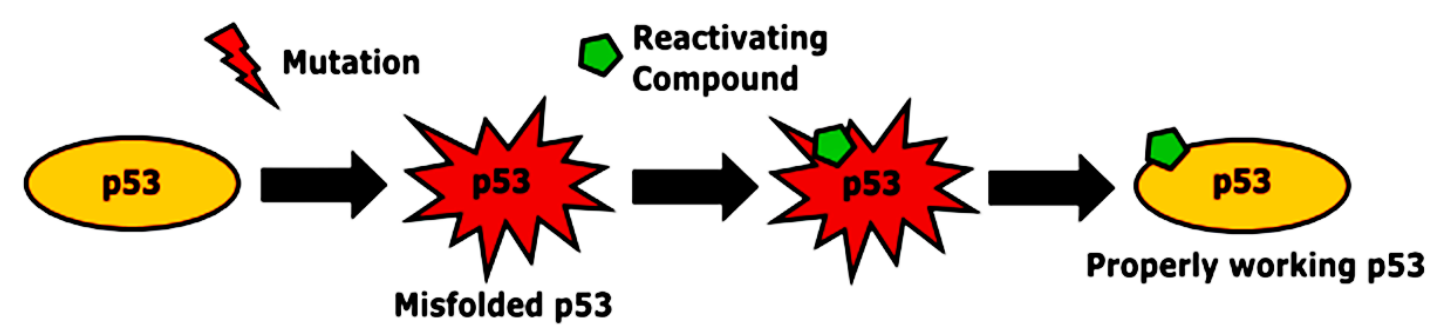

Figure 2: Restoration of p53 conformation by reactivating substances. In cancer cells, the p53 protein is often inactivated by mutations. By binding misfolded and inactivated p53, reactivating compounds can restore its active form and tumor suppressor function [67]. 
et al. mut-p53 is more amenable to this type of covalent modification than the wild-type version [80]. Interestingly, unfolded wt-p53 proteins are also modified by MQ. The degree of binding is correlated to the extent of unfolding [80].

In addition, a further benefit of PRIMA-1 is represented by its large therapeutic window [79]. Although normal cells seem to be more resistant at therapeutic doses, PRIMA-1 and APR-246 may target other proteins in addition to $\mathrm{p} 53$ [8]. How does MQ then achieve target specificity? One plausible explanation is that the structural aspect of a specific cysteine might dictate selectivity and cater to the modification of only a limited number of proteins. Furthermore, the active product, MQ, is generated from a prodrug, only after cellular uptake [8]. This may prevent extensive modification of extracellular proteins.

Several explanations have been suggested, as to how alkylation of thiol groups in mut-p53 could restore native conformation and function: (i) prevention of disulfide bond formation within the core domain of $\mathrm{p} 53$, (ii) alkylation-mediated escalation in the protein fraction capable of binding to DNA, (iii) formation of adducts in the core domain that may allow effective DNA-binding and consequent transactivation of p53 target genes, and (iv) PRIMA-1 adducts that create additional hydrophobic interactions with amino acids in the core via hydrogen bonding, thereby promoting accurate folding of the core [80].

Li et al. proposed new insights into PRIMA-1 ${ }^{\text {Met }}$ functionality [82]. PRIMA-1 ${ }^{\text {Met }}$ is the methylated analogue of PRIMA-1, in which one of the two hydroxyl-groups is replaced by a methoxy-group [82]. PRIMA-1 ${ }^{\text {Met }}$ limited the growth of colorectal cancer (CRC) cells irrespective of p53 status, although robust apoptosis was induced only in mut-p53 cells [82]. Upregulation of the pro-apoptotic protein NOXA was essential for PRIMA-1 $1^{\text {Met-mediated }}$ activity. It led to apoptosis associated with cleavage of PARP [Poly (ADP-ribose)-Polymerase, involved in DNA repair and programmed cell death] [82]. Contradictory to several previous studies, $\mathrm{Li}$ et al. reported that $\mathrm{CRC}$ cell lines with wt-p53 or p53-null cells also responded to PRIMA-1 ${ }^{\text {Met }}$ treatment [82]. Bykov and Wiman have put forward one credible mechanism accounting, at least in part, for the effects of the drug in p53-null cancer cells [69]. APR-246, on conversion into MQ, modifies TrxR1 (thioredoxin reductase 1) into an oxidase. The latter induces reactive oxygen species (ROS), which in turn contribute to APR-246-induced cell death [69]. However, in CRC cells with wt-p53 or p53-null cells, PRIMA-1 ${ }^{\text {Met }}$ mainly induces cytostasis, whereas the induction of apoptosis appears specifically in mut-p53 cells [82]. This study by $\mathrm{Li}$ et al. opens up avenues to attain greater efficacy in the use of PRIMA-1 ${ }^{\text {Met }}$ against cancer. However, a deeper understanding of the molecular mechanism is still required [82].

\section{MIRA-1}

Another mut-p53 function-restoring small molecule is MIRA-1 (mut-p53-dependent induction of rapid apoptosis) [67]. Although structurally MIRA analogues are distinct from PRIMA-1, the molecular mechanism involving reactivation of mut-p53 by MQ is quite similar [68]. MIRA-1 contains a maleimide group with 3-4 double bonds, which forms chemical bonds with thiol and amino groups. Thus, alkylation of cysteine and/or lysine residues of p53 by MIRA-1 stabilizes native folding of the protein. The alkylation status, however, depends on the accessibility of thiol groups. As a consequence, mutant and unfolded proteins are more effectively modified by MIRA-1 than is the correctly folded wild-type $[67,83]$.

Although MIRA-1 and PRIMA-1 both act via modification of thiol groups, they differ considerably in kinetics of cell death induction. MIRA-1 induces cell death much faster than PRIMA-1 does (6-12 h versus 24$48 \mathrm{~h}$ ). This could be attributed to the variable dynamics of cellular uptake or degradation as well as differences in their modes of action $[67,84]$. MIRA-1 induces cell killing in a mut-p53-dependent manner with a much higher potency than PRIMA-1, and MIRA-1-induced cell death involves DNA-fragmentation as well as caspase activation [67].

The maleimide groups of MIRA analogues react with thiol and amino groups of the protein through nucleophilic addition [67]. Presence of several double bonds within the maleimide group is critical for its activity. MIRA-1 acts by shifting the equilibrium of p53 towards the native conformation, which leads to restoration of p53-mediated transactivation of target genes such as $p 21$, MDM2 (murine double minute 2) and PUMA as well as induction of p53-dependent apoptosis [67].

MIRA-1 acts on multiple inter-connected pathways to induce apoptosis. In a recent study, Saha et al. evaluated the anti-myeloma activity of MIRA-1, both in vivo and in vitro [85]. The authors showed that the p53 status is not a decisive factor for induction of apoptosis by MIRA1 in multiple myeloma (MM) cells. The group used wt-, mut- and silenced p53 MM cells and observed that MIRA-1 treatment resulted in the induction of multiple signaling pathways implicated in apoptosis of MM cells [85]. Firstly, MIRA-1 treatment induced ER-signaling [85-87] by triggering activation of PERK (protein kinase R-like endoplasmic reticulum kinase), one of the ER stress sensors. PERK as well as eIF2- $\alpha$ (eukaryotic initiation factor 2) are phosphorylated and subsequently several chaperone proteins are activated (calnexin, protein disulfide isomerase (PDI) and binding immunoglobulin protein (BiP)) [85]. Consistent with their findings, the activation of pro-apoptotic PUMA and BAX as well as the repression of anti-apoptotic proteins like Mcl-1 and c-Myc have been shown to be linked to ER stress signaling pathways. Thus, they concluded that contrary to previous 
assumptions, MIRA-1 induces p53-independent apoptosis in $\mathrm{MM}$ cells primarily because of a change in the balance between pro- and anti-apoptotic proteins [85].

However, further studies are required to fully understand the modulatory mechanisms of MIRA-1associated intervention strategies in intracellular crosstalks leading to apoptosis. Simultaneously, the quest to identify prominent signaling molecules within those pathways becomes pertinent.

\section{AGENTS INTERRUPTING THE MDM2- P53-INTERACTION}

Despite the fact that nuclear levels of both p53 and MDM2 are normally kept at low levels due to a regulatory circuit, a deregulated MDM2/p53 balance, (e.g. by overexpression of MDM2) diminishes the tumor suppressive functions of p53 [12, 22]. Owing to this antagonizing effect of MDM2 on p53, small molecules have been developed that mimic p53-binding residues [37]. High-resolution crystal structures of MDM2 and p53 indicate that their interaction is mediated by a welldefined hydrophobic surface pocket and three hydrophobic key residues: Phe19, Trp23 and Leu26 [88]. The compact binding pocket in MDM2 enables scientists to design new small molecules capable of blocking the MDM2-p53 interaction. With this interaction blocked, p53 is no longer controlled by MDM2 and is reactivated in tumor cells harboring wt-p53 [38].

However, MDM2 is not the only negative regulator of p53 and therefore the other ones have to be kept in mind. P53 is cross-linked in a complex network with several other actors. For example, it is also regulated by the proteins SirT1 (Sirtuin 1) [160] or Wip1 (wt-p53 induced phosphatase/PPM1D) [162].

Sirtuin 1 is a NAD+-dependent histone deacetylase, which also deacetylates non-histone proteins involved in cell growth, apoptosis, tumorigenesis and cell senescence [160]. P53 becomes acetylated after DNA damage leading to increased transcriptional activity. SirT1 interacts with p53 and attenuates p53-mediated functions through deacetylation of p53 at its C-terminal residue (Lys382). Therefore, overexpression of SirT1 leads to the repression of normal p53-dependent response to DNA-damage or oxidative stress such as cell cycle arrest and apoptosis $[160,161]$.

Furthermore, the interaction between p53 and its other negative regulator Wip1 is controlled through an autoregulatory feedback loop, similar to MDM2. Wip1 is induced by genotoxic stress. It efficiently inhibited the $\mathrm{p} 53$ pathway by dephosphorylation of p53 at its transactivating domain Ser15 as well as by dephosphorylation of MDM2. Therefore, Wip1 promoted recovery from the G2 checkpoint and contributed to the termination of DNA damage response [162, 163, 164]. These facts affirm the necessity to decode the entire p53 interaction network as it would open new fields of research of novel chemotherapeutic agents.

Sriraman et al. tested, whether the simultaneous inhibition of both p53-antagonists, MDM2 and Wip1, induce p53 activation more potently than single inhibitors. Indeed, the inhibition of Wip1 fortified the effect of MDM2 antagonists alone on p53 activation [162]. Similar results were obtained by others [163, 164]. These findings emphasize the therapeutic potential of negative regulators of p53 such as MDM2, as well as other negative regulators and opens new possibilities of a multitarget chemotherapy in tumors harboring wt-p53.

Numerous MDM2 inhibitors have been developed during the past few years. An overview of some potent ones is presented in Table 4.

\section{MDM2 inhibitors}

\section{Nutlins}

Cis-imidazolines, also referred to as nutlins, are promising non-peptide small molecules that are well characterized MDM2 inhibitors [95]. They were the first selective small molecules that inhibited the wt-p53MDM2 interaction [92, 96, 97].

Crystal structure studies demonstrated that cisimidazolines bind to the p53-binding site of MDM2 by mimicking the interaction of critical amino acid residues [83]. Owing to their hydrophobic nature, Trp23, Phe19 and Leu26 fit excellently into the deep hydrophobic pocket of MDM2 [12].

P53's binding pocket on MDM2 is sterically inhibited by nutlin binding, thus inducing p53 accumulation and restoration of its transcriptional activity followed by apoptosis in MDM2-overexpressing tumor cells [98]. The compounds induce stabilization of p53, induction of p21 target genes, cell cycle arrest as well as apoptosis [99].

Three compounds (nutlin-1, -2 and -3) exhibited suitable $\mathrm{IC}_{50}$ values to block the p53-MDM2 interaction [83] (Table 4, Table 5). They possess the same core structure and exhibit only slight variations in their functional groups [95]. These nutlins harbored sufficient cell permeability and elicited dose-dependent accumulation of wt-p53. However, none of them induced cell cycle arrest or upregulated p53 downstream gene targets in mut- or p53-null tumor cells [92]. Hence, it is proposed that only wt-p53 cell lines are sensitive to these compounds. The active enantiomer of nutlin-3a, induced apoptosis in osteosarcoma cells at much lower doses, whereas its inactive enantiomer was ineffective even at higher concentrations [83].

Nutlin-3 possessed activity against a broad panel of cancer cells harboring wt-p53 in vitro and in vivo [96]. It activated p53 transcriptional activity in osteosarcoma, retinoblastoma, lymphoblastic leukemia, colon and 
Table 4: Overview of important and promising MDM2 inhibitors

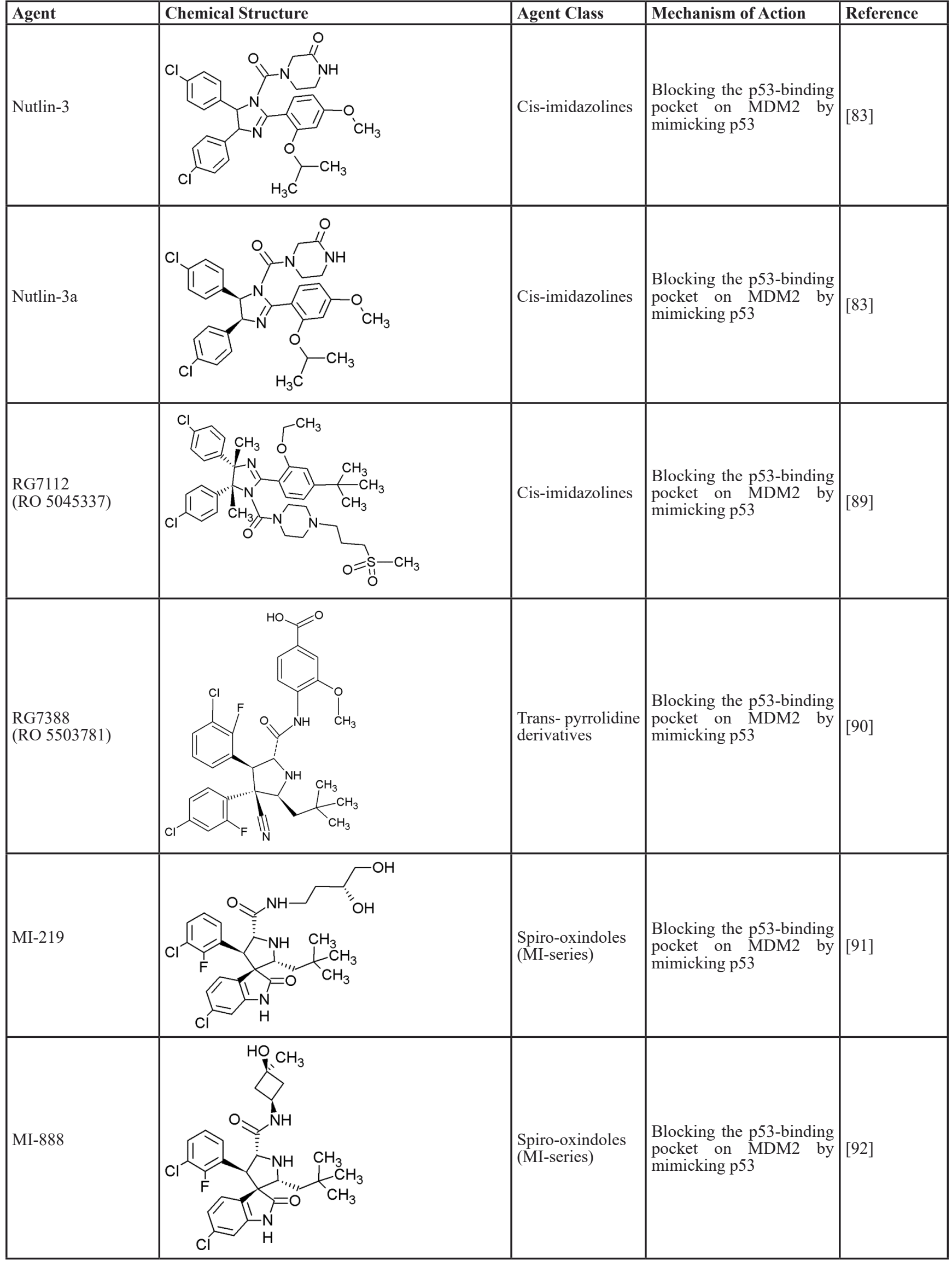




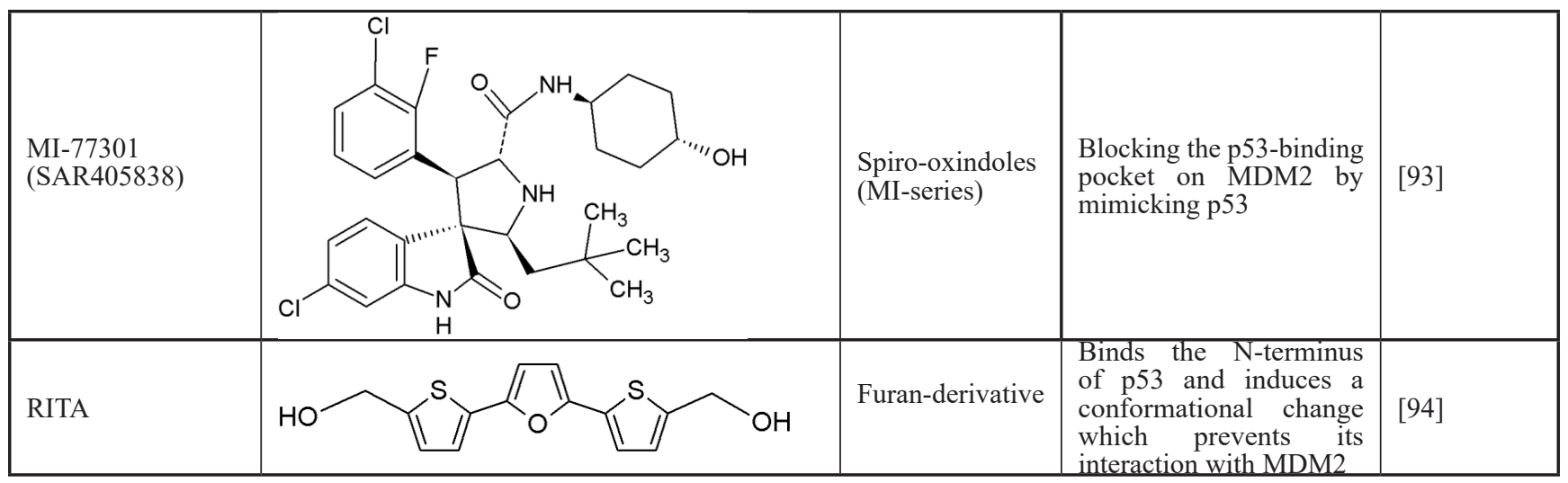

breast cancer cell lines [96]. In combination with chemoradiotherapy, the compound showed synergistic activity against prostate [100] and lung cancers [101, 102] as well as lymphocytic leukemia [103] and neuroblastoma [104]. Furthermore, nutlin-3 showed normal cell protective efficacy against the detrimental effects of chemotherapy by inducing cell cycle arrest [105] due to inhibition of BAX and BAK (Bcl2-antagonist/killer) [106].

However, the activity of nutlins strongly suffer from p53 downstream aberrations, such as MDMX overexpression [92]. Overexpressed MDMX (murine double minute $\mathrm{x}$ ) limits the effectiveness of nutlin-based chemotherapy [92]. Since nutlins do not bind MDMX, cis-imidazolines reduce MDMX protein levels in wt-p53 cancer cells by facilitating MDM2-dependent degradation [107]. In cancer cell lines resistant to cis-imidazolines, a combination therapy with doxorubicin may be effective to overcome resistance. The DNA-damaging anticancer drug doxorubicin effectively depleted MDMX levels and therefore revealed synergistic effects in combination with nutlins $[83,107]$.

Synergistic effects of nutlin-3 with cytostatic drugs have been reported. Deben et al. investigated the benefits combination of nutlin-3 with cisplatin in sequential treatments (cisplatin followed by nutlin-3) [108]. They used a series of NSCLC cell lines with differential p53 status. Although nutlin-3 showed good efficacy even as single agent, the authors hypothesized that the anti-tumor effect might be enhanced, if given in combination with DNA-damaging agents [108]. Cisplatin and nutlin-3's sequential treatment resulted in a synergistic cytotoxic response in wt-p53 cell lines [108]. A significant increase in p53's targets could be observed. Augmented protein levels of MDM2, p21, PUMA and BAX led to cell cycle arrest at G2/M followed by apoptosis [108]. The group also illustrated that combinatorial therapy of small molecules with DNA-damaging agents (cisplatin) resulted in a synergistic cytotoxic response [108].Unravelling the full importance of nutlin-based combination treatments demands further evaluation.

Another study by Wang and co-workers in 2012 investigated the efficacy of nutlin-3a (Table 4) treatment in osteosarcoma cell lines both in vivo and in vitro [109]. Employing three osteosarcoma cell lines [U-2 OS (wt p53), SaOS2 (null p53), MG63 (mut-p53)], the authors deciphered that activation of the $\mathrm{p} 53$ pathway due to the disruption of p53-MDM2-interaction by nutlin-3a depends on the presence of wt-p53 [109]. Nutlin-3a stabilized p53 and led to dose-dependent anti-proliferative and cytotoxic effects, inducing cell cycle arrest at G1 phase and apoptosis both in vivo and in vitro [109]. Significant apoptosis and increased G1 phase fractions were detected, if treated with $10 \mu \mathrm{M}$ nutlin-3a. Further treatment with nutlin-3a significantly upregulated p53 and p21 levels in osteosarcoma cells [109]. In a quest to investigate, whether nutlin-3a suppresses growth of xenograft tumors in nude mice, Wang et al. showed that it was well tolerated at a daily dosage of $25 \mathrm{mg} / \mathrm{kg}$ administered intraperitoneally for 14 days. This treatment regimen resulted in $85 \%$ inhibition of tumor growth [109].

Tonsing-Carter et al. evaluated the combination treatment for triple negative breast cancers (TNBC) [110]. Due to its aggressive nature (lacking hormone receptors) $[111,112]$, the development of efficacious therapies for TNBCs is extremely challenging. Tonsing-Carter et al. combined a platinum-based regimen with nutlin-3a. Single and combination treatments of nutlin-3a and carboplatin were tested on a panel of TNBC cell lines with mut-p53 [110]. Due to the inhibition of protein-protein interactions between MDM2 and several of its binding partners including p53, p73 $\alpha$ (another tumor suppressor involved in cell cycle regulation and induction of apoptosis with structural resemblance to $\mathrm{p} 53$ ), transcription factor E2F1 (involved in cell cycle and action of tumor suppressor proteins) and Hif- $1 \alpha$ (hypoxia inducible factor $1 \alpha$ ) [113115], the use of nutlin-3a led to the activation of several pathways associated with anti-cancer effects [110]. The effect of nutlin-3a was especially beneficial, if it was administered in combination with DNA-damaging drugs. Platinum agents, such as carboplatin, form DNA-platinum adducts leading to double-strand DNA breaks and cell death [116]. In vitro studies showed strong synergy between carboplatin and nutlin-3a [110]. In TNBC cells with mut-p53 background, increased cell death 
Table 5: First nutlin derivatives

\begin{tabular}{|c|c|c|c|c|}
\hline Agent & Chemical Structure & Agent Class & Mechanism of Action & Reference \\
\hline Nutlin-1 & & Cis-imidazolines & $\begin{array}{l}\text { Blocking the p53-binding } \\
\text { pocket on MDM2 by } \\
\text { mimicking p53 }\end{array}$ & {$[83]$} \\
\hline Nutlin-2 & & Cis-imidazolines & $\begin{array}{l}\text { Blocking the p53-binding } \\
\text { pocket on MDM2 by } \\
\text { mimicking p53 }\end{array}$ & [83] \\
\hline
\end{tabular}

was detected, if administered in combination, as well as decreased $\mathrm{IC}_{50}$ values for both drugs. Cleaved PARP was detectable in $100 \%$ of tumors following combination treatment, whereas it was only detectable in $50-66 \%$ of tumors treated with carboplatin or nutlin-3a alone [110]. Further inhibition of MDM2 by nutlin-3 increased the pool of available p $37 \alpha$, which in turn activated proapoptotic gene expression and finally promoted apoptosis [110]. Combinatorial treatment significantly inhibited tumor growth with no serious physical complaints such as dehydration, diarrhea or bleedings within the gastrointestinal tract [110]. Besides primary tumor growth, even metastatic foci in the lung decreased in size and number relative to single-agent therapy. This was due to an efficient delivery of nutlin-3a to the lung, as suggested by the pharmacokinetic data [110]. Owing to these promising results, combinatorial therapy of nutlin- $3 \mathrm{a} /$ carboplatin deserve further development as new clinical therapies.

Tovar et al. described a more potent inhibitor of the p53-MDM2 interaction than the original nutlins [89]. RG7112 (Table 4) is an advanced derivative of the class of cis-imidazolines [90]. It displaced p53 peptides from the surface of MDM2 with a 4-fold higher potency than nutlin-3a [96]. Furthermore, RG7112 showed improved binding due to faster on-rate and slower off-rate, and also exhibited improved pharmacological properties [89]. In crystal structure studies, RG7112 was found to bind to MDM2 at the same region as the other nutlins [89]. The two chlorophenyl groups of RG7112 project into the Leu26 and Trp 23 pockets and the ethoxy group of the third benzene ring bound into the Phe19 cave of MDM2 [90]. However, compared to the other compounds of the nutlingroup, RG7112 possessed a 4,5-dimethyl substitution at the imidazole ring. This modification caused more structural rigidity, blocking its metabolic conversion in to an inactive imidazole [89].

In addition to these studies, Ding et al. investigated a novel nutlin, RG7388 (RO5503781) (Table 4), which induced p53-stabilization in a dose-dependent manner, as well as cell cycle arrest and apoptosis [90]. Although the mode of action is similar, RG7388 achieved a significantly higher in vivo efficacy against human osteosarcoma xenografts tumors than RG7112. Even at lower doses, the efficacy of RG7388 was much higher than RG7112. At $50 \mathrm{mg} / \mathrm{kg}$ body weight, RG7112 achieved 74\% tumor growth inhibition, whereas RG7388 obtained 84\% growth inhibition at much lower doses $(12.5 \mathrm{mg} / \mathrm{kg})$ [90]. In conclusion, RG7388 was more potent than RG7112.

\section{Benzodiazepinediones}

1,4-benzodiazepine-2,5-diones (BDPs) are another class of small molecule inhibitors interacting at the p53-MDM2 site [92, 117] (Table 6). Grasberger and coworkers (2005) first reported 1,4-benzodiazepine-2,5diones as inhibitors of p53-MDM2 interaction [118]. Compound 21 discovered by high-throughput screening of over 338000 compounds achieved a promising $\mathrm{IC}_{50}$ value [119]. Modifications of this scaffold led to significant increases in potency. Due to the introduction of a 4-chloro substitution on the phenyl rings of the scaffold, compound 23 exhibited much lower $\mathrm{IC}_{50}$ values [120]. An MDM2-23 co-crystal structure demonstrated the interaction between BDPs and MDM2. The three phenyl rings of compound 23 bound to MDM2 by mimicking the conformation of the p53 triad motif [121].

Although a large number of subsequently 
synthesized compounds achieved improved efficacies, they frequently exhibited poor pharmacokinetic properties and poor cell permeability. However, compound 27 demonstrated promising activity in MCF7 breast cancer cells [122]. In vivo studies with melanoma tumors showed that compound 27 enhanced the activity of doxorubicin, if applied in combination [123]. These compounds in combination, led to tumor growth inhibition at doses that are inactive, if administered alone. The combination resulted in reduced toxicity due to lower required dosages [83]. This points to the therapeutic benefit of small molecules in combination therapies.

Furthermore, several other thio-benzodiazepine compounds have been examined with respect to their structure-activity relationship and antitumor activity [95]. Several substances achieved high binding affinities with MDM2 and two of them, $8 \mathrm{i}$ and 8n, stood out particularly. These compounds showed excellent binding activities, which were even superior to the reference compound nutlin-3a [95]. Molecular docking studies of the thiobenzodiazepine-MDM2 complex illustrated that the binding interaction was mediated by three hydrophobic pockets that are filled by the three aromatic rings of the thiobenzodiazepines. The well positioned ester-group of the thio-benzodiazepines, functioning as hydrogen bond acceptor with Gly16, may account for the enhanced binding affinity [95]. Even in vitro, most compounds showed moderate to excellent cytotoxicity towards cancer cells. Some compounds, including $8 \mathrm{i}$ and $8 \mathrm{n}$, showed even better biological activity than nutlin-3a in wt-p53 osteosarcoma cells [117]. Thus, compounds 8i and 8n represent promising new MDM2 inhibitors that require further evaluation.

\section{Spiro-oxindoles}

Yet another group of small molecules that hold large promise in inhibiting the p53-MDM2 interaction are the spiro-oxindoles [124] (Table 4, Table 7). The oxindole ring of these compounds mimics the side chain of Trp23 of p53, which is critical for MDM2 binding. The hydrophobic-substituted spiropyrrolidine-ring imitates the side chains of Phe19 and Leu26 [90, 124]. Extensive crystal-structure analyses have revealed that Leu22 is also critical for binding p53 and MDM2 [124], indicating the potential of oxindole derivates [92].

MI-63 and MI-219 are two spiro-oxindoles with improved structures. Although MI-63 showed prominent in vitro activity, its in vivo pharmacokinetic profile was unsatisfactory [92]. MI-219 on the other hand, was more effective owing to its high binding affinity for MDM2 and good oral bioavailability and better pharmacokinetic profile [92].

In a recent study by Samudio et al., the potential of MI-63 in acute myleoid leukemia (AML) revealed significance [125]. In AML cell lines and tissue samples, MI-63 elicited p53-dependent cytotoxicity as well as apoptosis. The disruption of MDM2-p53 interaction by MI-63 led to enhanced p53-levels and levels of target genes (e.g. p21). This also correlated with G1-cell cycle arrest and apoptosis induction [125]. Interestingly, MI63 treatment depleted MDM4 (mouse double minute 4, also known as MDMX) protein levels [125]. MDM4, like MDM2, is an inhibitor of p53 activity [125]. The decline in MDM4-protein levels was proposed as consequence of MDM2-mediated proteasomal degradation [125]. Another plausible mechanism might be reduced transcription of MDM4 [125].

The drug-induced impediment of the MDM2-p53 interaction increased p53 levels, leading to the upregulation of p53 target genes and wt-p53-dependent induction of apoptosis in several human breast, colon and prostate cancer cell lines [105]. In vivo xenograft tumor experiments revealed a complete inhibition of tumor growth at non-toxic doses. Administration of MI-219 (300 $\mathrm{mg} / \mathrm{kg}$ ) for 14 days caused complete suppression of tumor growth, decreased the tumor volumes and showed no signs of toxicity $[92,98]$.

In another study by Sosin and colleagues, differential effects of MI-219 were tested against lymphoma cell lines and patient-derived non-Hodgkin's SLL (small lymphocytic lymphoma)/CLL (chronic lymphocytic leukemia) samples [91]. Compared to nutlin-3, MI219 triggered an earlier response after treatment (nutlin-3: 48 h, MI-219: 12-24 h) and enhanced MDM2autoubiquitination as well as degradation at equivalent concentrations [91]. Cell death induction by MI-219 was more effective and occurred earlier than by nutlin-3 [91]. Also, the enhanced efficacy of MI-219 was associated with a significant increase of p53-induced p53AIP1 (p53regulated apoptosis-inducing protein 1) [91]. Reasons for MI-219s' enhanced efficacy over nutlin-3 include differential binding affinities (7-fold higher) or variations in bioavailability [91]. Another reason for the increased efficacy of MI-219 is that MI-219 mimics four key binding residues in p53 (Phe19, Leu22, Trp23 and Leu26) in comparison to the three residues in the case of nutlin-3 (Phe19, Trp23 and Leu26) [91]. As a result, the former compound was subjected to chemical optimization in hydrogen binding and hydrophobic interactions [91].

One more compound amongst the arsenal of the MIseries, MI-43 preferentially inhibited the growth of wt-p53 cells. It induced growth arrest in G1 and G2 phases of cell cycle at low concentrations as a result of p21-induction. At higher doses, it induced PUMA/NOXA-evoked apoptosis. MI-43 was less toxic towards normal lung cells than cancer cells and sensitized cancer cells to etoposideinduced apoptosis, if used in combination [98] [105].

MI-888 is another new derivate with an excellent pharmacokinetic profile and enhanced in vivo efficacy [99]. It achieved a promising $\mathrm{K}_{\mathrm{i}}$-value and produced rapid, complete and durable tumor regressions after oral administration in two human xenograft tumor models 
Table 6: Overview of some benzodiazepinediones undergoing first steps of investigation

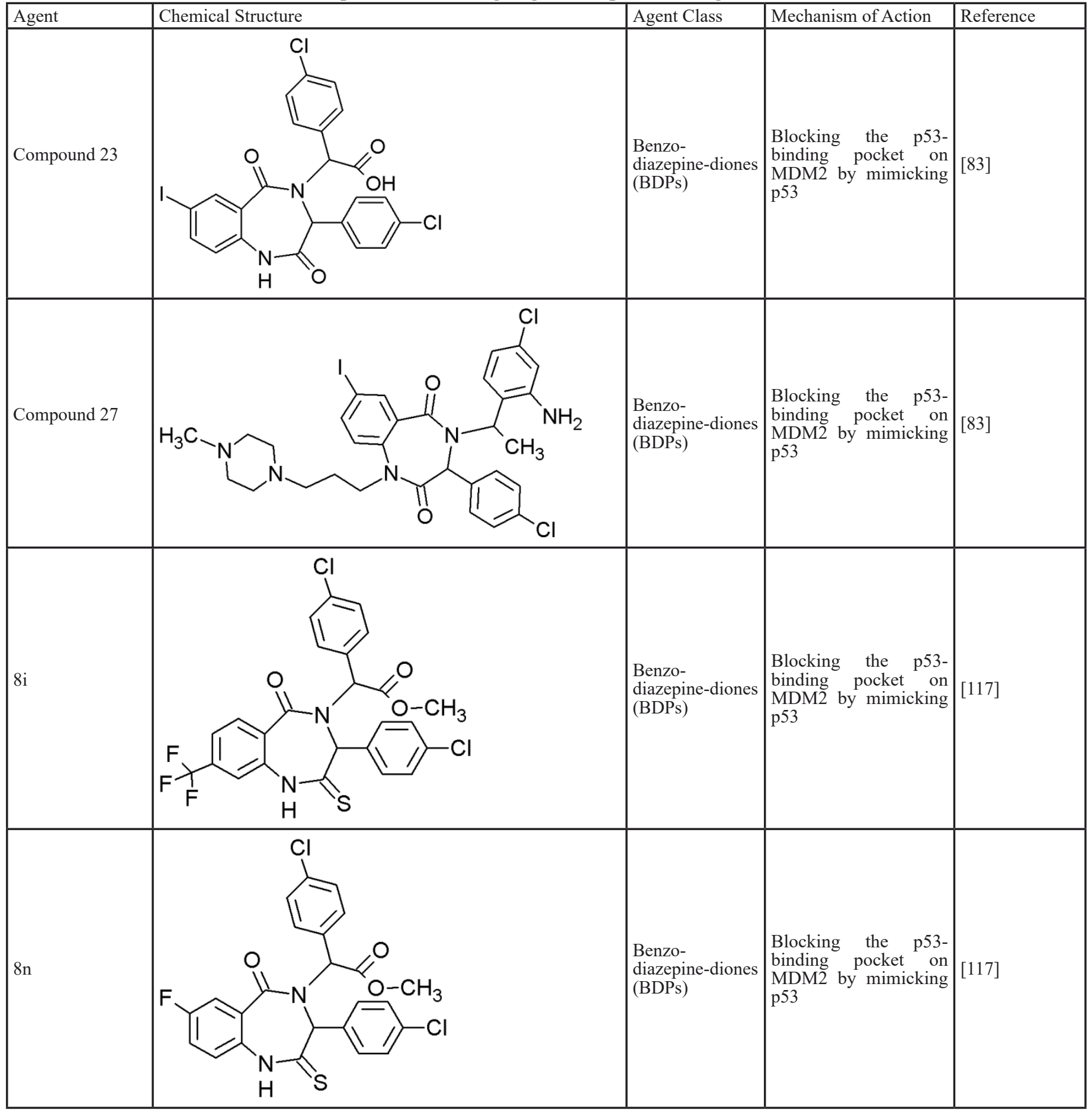

(osteosarcoma and acute lymphoblastic leukemia) [99].

SAR405838, also termed MI-77301, is another small molecule inhibitor of the p53-MDM2 interaction [93]. SAR405838 is a highly optimized compound in the spiro-oxindole family [127]. Its binding mode is similar to that of other spiro-oxindoles. It mimics the three key residues of p53 (Phe19, Leu26, Trp23) [93]. But unlike the other compounds, SAR405838 captures additional interactions. The $\mathrm{C} 1$ atom of its oxindole group shows hydrophobic interactions with MDM2. The imidazole side chain of His96 in MDM2 and the carboxyl group of SAR405838 interact via a hydrogen bond. Even $\pi$ - $\pi$ stacking is present between the His96 of MDM2 and the 2-fluoro-3-chlorophenyl of SAR405838 [93]. In contrast with the co-crystal structures of p53-MDM2 and nutlinMDM2, in SAR405838-MDM2, the N-terminus of MDM2 forms extensive interactions with SAR405838. This is due to re-folding of residues 10-18 of MDM2, 
Table 7: Further, less relevant compounds of the MI-series

\begin{tabular}{|c|c|c|c|c|}
\hline Agent & Chemical Structure & Agent Class & Mechanism of Action & Reference \\
\hline MI-43 & & $\begin{array}{l}\text { Spiro-oxindoles } \\
\text { (MI-series) }\end{array}$ & $\begin{array}{l}\text { Blocking the p53-binding pocket } \\
\text { on MDM2 by mimicking p53 }\end{array}$ & {$[126]$} \\
\hline MI-63 & & $\begin{array}{l}\text { Spiro-oxindoles } \\
\text { (MI-series) }\end{array}$ & $\begin{array}{l}\text { Blocking the } p 53 \text {-binding pocket } \\
\text { on MDM2 by mimicking p53 }\end{array}$ & [83] \\
\hline
\end{tabular}

which interact with SAR405838 through Val14 and Thr16 [93]. Through these additional interactions, SAR405838 achieves high binding affinities [93].

Bill et al. reported the preclinical effects of SAR405838 in both in vitro and in vivo dedifferentiated liposarcoma models [127]. SAR405838 restored downstream signaling through pharmacological MDM2 inhibition. The increase of p53-induced apoptotic genes $B A X$ and PUMA suggests that the treatment activated the p53 pathway [127]. Expression of apoptosis-associated genes (e.g. p21, PUMA and BAX) was proportionate with increasing concentrations of SAR405838 [127]. This compound further demonstrated a promising oral pharmacokinetic profile in mice. Even if administered as single agent, it induced apoptosis at low concentrations [127]. SAR405838 promoted complete tumor regression after oral administration of $200 \mathrm{mg} / \mathrm{kg} / \mathrm{wk}$, whereas other potent MDM2-inhibitors (RG7112 and RG7388) did not achieve this effect [127]. The functional outcomes of SAR405838 strongly depend on the presence of MDM2 amplifications. Bill et al. showed that no effects were visible in wt-p53 liposarcoma cells without overexpression of MDM2. Therefore, SAR405838 treatment only induced apoptosis in cancer cells harboring $M D M 2$ amplifications [127]. In conclusion, SAR405838 showed very promising preclinical data. It is a potent and highly effective MDM2inhibitor and is currently undergoing clinical trial [93].

\section{RITA}

RITA (reactivation of $\mathrm{p} 53$ and induction of tumor cell apoptosis) is a furan derivative [2,5-bis(5hydroxymethyl-2-thienyl)furan] and was identified in a cell-based screen for wt-p53-reactivating molecules [20, 98] (Table 4).

RITA bound to the N-terminus of p53 (residues 1-63) and induced a conformational change, which propagated from the $\mathrm{N}$-terminus to the core and $\mathrm{C}$-terminal domain, advocating the interruption of $\mathrm{p} 53$ and MDM2 $[12,94,98]$. This led to $\mathrm{p} 53$ accumulation and induction of p53-dependent apoptosis in a variety of tumor cell lines of different origin including carcinomas of lung, colon, breast, skin; melanoma and diverse lymphomas [128]. Possibly, the binding of RITA to the N-terminus affected the hydrogen bonds within the MDM2-binding site, preventing the formation of the $\alpha$-helix, which is necessary for MDM2 binding [20]. Low concentrations of RITA inhibited growth of carcinoma cells harboring wt p53, but showed minimal effect on cells lacking it [92]. In contrast to other MDM2 inhibitors, RITA activated $\mathrm{p} 53$ by binding to it instead of binding to MDM2 [92]. Furthermore, RITA suppressed the growth of human xenograft tumors in mice without causing toxic effects in normal tissues [68]. This led to the assumption that RITA may selectively activate p53 in tumor cells. Although nutlin-3a and RITA target the same protein complex, they induce different biological outcomes. Disruption of the p53/MDM2 complex may not be the only effect of these compounds [129]. Nutlin3a changes the repertoire of MDM2-binding partners, whereas RITA affects p53 interactions. Burmakin et al. found that besides MDM2-p53 interaction, RITA also disrupted other p53 binding interactions such as with iASPP (inhibitor of apoptosis-stimulating protein of p53), Parc (p53-associated Parkin-like cytoplasmic protein) or E6-AP (E6-associated protein) [94]. In addition, p53 
activated by RITA induced the expression of Fbxw7 (F-Box and WD repeat domain containing 7), which has a critical function in the degradation of N-Myc, a protein that correlates with a poor prognosis and resistance to therapy [94]. Transcription of Aurora A, an antagonist of Fbwx7-mediated degradation of N-Myc, was repressed by p53 [94]. In addition to its potential as wt p53 reactivating substance, RITA also exhibited paramount efficacy as mut-p53 activator.

The discovery of the mutant reactivating ability of RITA was serendipitous. Initially, Zhao et al. screened for wt-p53-activating substances [22]. RITA led to restoration of the p53-mediated transcriptional program and induction of p53-dependent apoptosis [68]. Remarkably, RITA reactivated a broad range of different p53 mutant species, including those that were mutated at three residues [83]. Therefore, a general mechanism of action has been suggested through which restoring the function of different types of mutants was achieved. However, the exact molecular mechanism has not been deciphered. RITA-induced cell death involved DNA-fragmentation, cytochrome $\mathrm{C}$ release, caspase activation, and apoptosis [83]. Zhao et al. found RITA to be more efficacious than PRIMA-1 in inducing cell death in a mut-p53-dependent manner. RITA achieved much lower $\mathrm{IC}_{50}$ values than PRIMA-1 [22]. Interestingly, the kinetics of cell death induction considerably differed between different cell lines. While death induction in skin cancer cells harboring mut-p53 protein took only 6-8 h, breast cancer cells required several days [22]. Such kinetic differences could result from differential kinetics of cellular uptake and/or degradation of RITA or a different set of p53 inhibitors/ activators present in these cells [22].

Weilbacher et al. demonstrated that there was no strict link between cancer cell sensitivity to RITA and the p53 status in tumor cells. Even in p53-null cells, RITA was capable of inducing apoptosis [130]. Besides the fact that RITA interacts with TrxR1 (thioreduxin reductase 1) thus inducing ROS, it also promoted DNA damage [130]. Further, the authors proposed that JNK (c-Jun N-terminal kinases)/SAPK (stress-activated protein kinases) and p38 MAPK (mitogen-activated protein kinases) pathways are important in p53-deficient cells for caspase-dependent mitochondrial cell death [130]. JNKs translocate to the mitochondria, where, by modulating pro- and antiapoptotic BCL-2 (B-cell lymphoma 2) family proteins, they activate BAX and BAK to initiate apoptosis [130].

The benefits of using compounds that target wt-p53 as well as mut-p53, like RITA, have been illustrated by Burmakin et al. They demonstrated that RITA restored wt- and mut-p53 activities and induced p53-dependent apoptosis in neuroblastoma in vivo and in vitro [94]. RITA treatment disrupted MDM2/p53-complexation and inhibited the interaction between MDMX (another regulator of p53) and p53 [94]. This results is of enormous importance, particularly in developing compounds that simultaneously target wt- and mut-p53 cancer cells. Such a treatment may reduce the emergence of drug resistance and enhance the clinical treatment successes [94]. Aziz et al. demonstrated that cancer cells can develop resistance to nutlin-3a [131]. Continuous treatment of mut-p53 cancer cells with nutlin-3a resulted in acquired p53 mutations [131]. These acquired p53 mutations could be a result of mis-repaired DNA breaks in cells that initiated, but did not finish the process of apoptosis [131]. Therefore, the development of therapies that simultaneously restore wtand mut-p53 could be highly beneficial [94].

\section{Novel drug developments}

\section{Xanthone derivatives}

Xanthone derivates exhibit antitumor activity [132, 133]. Especially, prenylated xanthone derivatives have great potentials against breast cancer cell lines (MCF7) harboring wt-p53 and overexpressed MDM2 [132]. Leão and co-workers identified a set of 14 putative MDM2 ligands with xanthone scaffold by virtual drug screening leading to the identification of pyroxanthone 1 (3,4-dihydro-12-hydroxy-2,2-dimethyl-2H,6H-pyrano [3,2-b]xanthen-6-on) [16] (Figure 3). This pyroxanthone derivative was effective against human tumor cells with wt-p53. It mimicked p53 activators by activating p53-dependent transcription and upregulation of p53 downstream signals. Pyroxanthone 1 bound to MDM2 in similar manner as nutlin-3a [16]. However, the compounds interacted differently. While the interaction between pyroxanthone 1 and MDM2 involved a hydrogen bond with Gly58, the nutlin-3a-MDM2 interaction mainly involved hydrophobic interactions [16]. Pyroxanthone 1 represented a useful lead compound for further structurebased design of more potent analogs.

\section{Trisubstituted aminothiophenes}

Another series of inhibitors of the p53-MDM2 interaction are derivatives of a novel scaffold (MCL0527) [27] (Table 8). These derivatives revealed commendable MDM2 binding affinities and anti-proliferative effects against several cancer cell lines [105]. Derivatization at the 2-amino group and modification at the 3-carboxygroup have been carried out to find more potent inhibitors [32]. Compound 24, showed the highest binding affinity effectively inhibited MDM2 binding, it did not exhibit sufficient cytotoxicity towards tumor cells. However, compound 9 inhibited both p53-MDM2 binding and tumor cell proliferation [32].

To examine possible binding modes of MCL0527 and compound 24, Wang and co-workers performed molecular docking studies [32]. The thiophene ring, an important core structure, revealed three hydrophobic substituents in MDM2 binding clefts. The two 4-chlorophenyl groups and one methyl ester/N-benzyl 
group mimicked the three key residues Leu26, Phe19 and Trp 23 of p53 to form hydrophobic interactions. The methyl ester of MCL0527 did not occupy the spare room at the Phe19 binding site, as did the N-benzyl group of compound 24 [32]. This may be an explanation for its enhanced affinity. Some of these compounds exhibited even better anti-proliferative activity against wt-p53 cells than nutlin-3 [32]. Regarding wt-p53 selectivity, several compounds showed at least 3-fold inhibitory selectivity in wt-p53 cell lines compared to p53-null cell lines [32]. Hence, 3,4,5-aminothiophenes may be valuable contenders in cancer therapeutics targeting the MDM2-p53 interaction.

\section{Natural products as MDM2 inhibitors}

\section{$\alpha$-Mangostin and gambogic acid}

$\alpha$-Mangostin and gambogic acid are prenylated xanthones derived from the mangosteen fruit of Garcinia mangostana L. (Clusiaceae) and resin of Garcinia hanburyi Hook.f. (Clusiaceae), respectively (Table 9). Both $\alpha$-mangostin and gambogic acid inhibited the p53MDM2 interaction by binding to MDM2 [134]. Their cytotoxic activity against human cell lines $[135,136]$ as well as their antitumor activity in animals $[137,138]$ are already known. Gambogic acid induced apoptosis and cell cycle arrest in human tumor cells harboring wt-p53 [139]. Furthermore, $\alpha$-mangostin showed cytotoxicity in human mut-p53 tumor cells [140]. p53-dependent transcriptional activity increased under treatment with these compounds, and thereby the negative effect of MDM2 on p53 was inhibited [134]. The predicted binding interactions between $\alpha$-mangostin/gambogic acid and MDM2 are similar to those between nutlin-3a and MDM2. These compounds bind near the p53-binding site, filling the space that is necessary for the interaction with $\alpha$-helix motifs in the p53 amino terminal domain. The two compounds revealed high binding affinities with the residues Gly58, Asp68, Val75 and Cys77 of the hydrophobic MDM2 binding site. Only gambogic acid formed hydrogen bonds with residues Gln72 and Phe55 of MDM2 [134, 141].

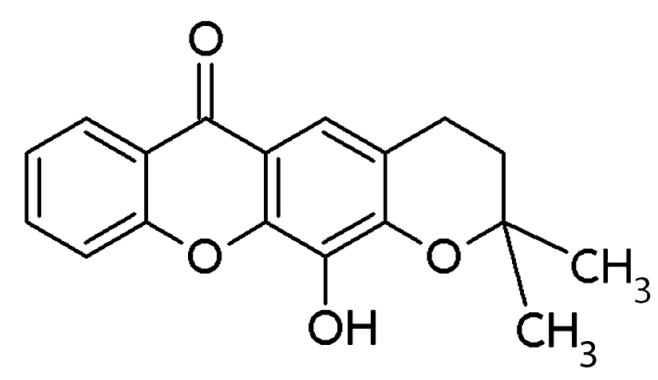

Figure 3: Structure of pyroxanthone 1.

\section{Siladenoserinols}

The screening of extracts from marine invertebrates in quest of MDM2 inhibitors led to the identification of 12 sulfonated serinol derivatives (siladenoserinol A-L) from tunicates belonging to the Didemnidae family [142]. Each of them contained a 6,8-dioxabicyclo [3.2.1] octane unit with either glycerophosphocholine or glycerophosphoethanolamine moieties and inhibited the p53-MDM2 interaction [142]. Despite their structural similarities, they showed extreme differences in their $\mathrm{IC}_{50}$ values. siladenoserinol A emerged as the most cytotoxic compound [142] (Figure 4). More studies are warranted to optimize the inhibitory effect of siladenoserinols and elucidate their molecular mechanisms.

\section{SMALL MOLECULES: NEW OPPORTUNITIES WITH CHALLENGES}

In the recent years, great efforts have been invested in the evaluation of novel small molecules that could act on the MDM2-p53 axis and function as mut-p53 reactivators. Despite initially promising outcomes only a few of the discovered small molecules exhibited the right combination of suitable properties to justify their entry into clinical trials. Many of the compounds were characterized by poor pharmacokinetic profiles.

RG7112, an advanced compound of the class of cis-imidazolines with high efficacy and selectivity, is currently in clinical trials [89]. However, serious side effects of RG7112 posed a critical issue for its clinical use [143]. Besides gastrointestinal toxicity (including nausea and vomiting), hematological toxicity (neutropenia and thrombocytopenia) was also observed [143-145]. Therefore, strict clinical monitoring is required and the effects of long-term exposure need to be evaluated [143].

A major obstacle to the clinical use of wt-p53 activators is the acquisition of p53 mutations during treatment [146]. Maki and coworkers demonstrated that wt-p53-harboring cancers lead to resistant clones with acquired p53 mutations, if chronically treated with nutlin3a [131]. At this juncture, it must be kept in mind that overexpression of MDM4, a MDM2 homolog and another

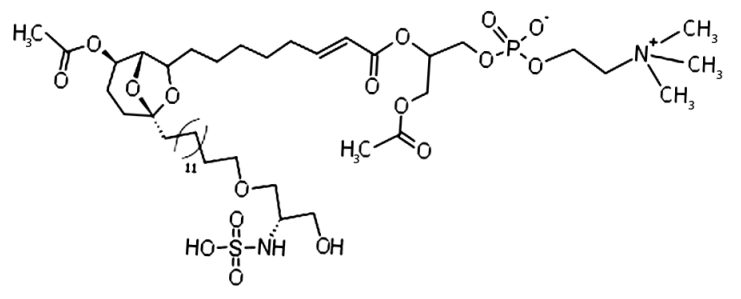

Figure 4: Structure of the marine compound siladenoserinol A. 
Table 8: Structures of 3,4,5-trisubstituted aminothiophenes.

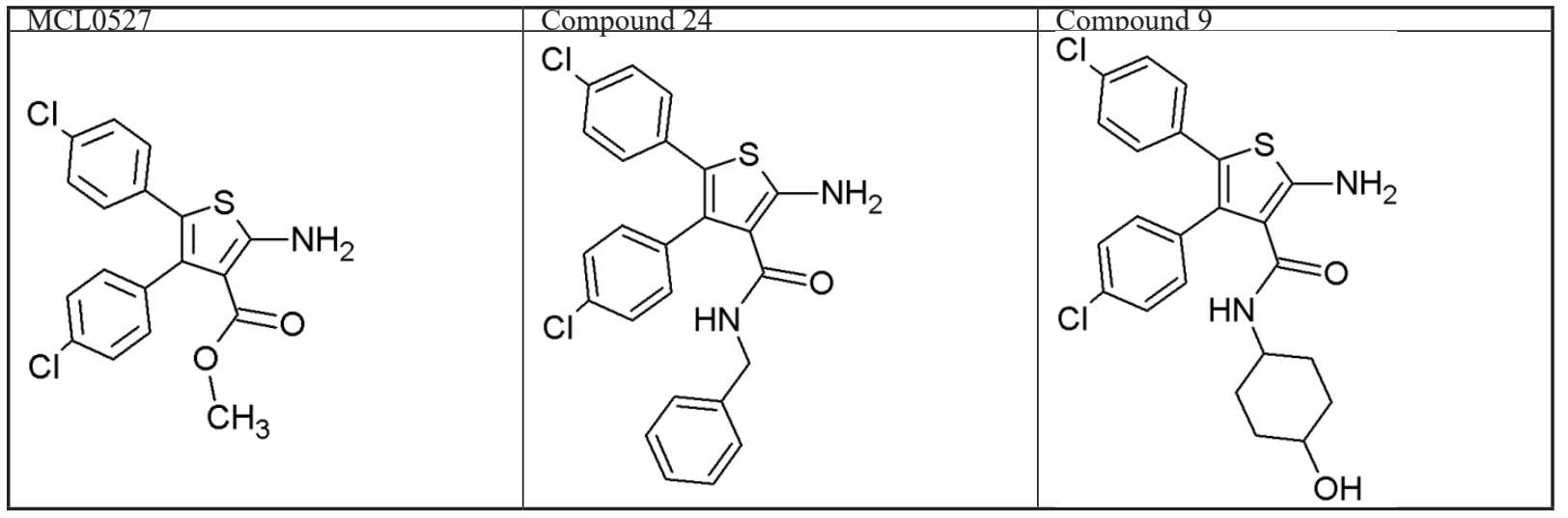

Table 9: Naturally derived compounds $\alpha$-mangostin and gambogic acid<smiles>COc1c(O)cc2oc3cc(O)c(CC=C(C)C)c(O)c3c(=O)c2c1CC=C(C)C</smiles>

potent negative regulator of $\mathrm{p} 53$, also led to decreased efficacy of nutlin-induced p53-activity and caused inadequate responses to nutlin treatment [147].

It is also possible that activation of p53 may lead to senescence, but not apoptosis, which could be hazardous in long term use [146]. Mirzayans et al. supported this assertion that the primary response to p53 activation in wt-p53 cancer cells may represent a form of senescence [148]. This may be problematic, if these cells eventually escape senescence and re-enter cell cycle [146].

A further challenge that needs to be dealt with is the potential of activating wt-p53 in non-cancerous, healthy tissues, which could have toxic effects [146]. This effect has been studied using mice with a hypomorphic allele of MDM2. These mice showed a phenotype with increased p53-dependent apoptosis in lymphocytes and epithelial cells [149]. This did not affect the lifespan of the mice, but it did affect their size [146]. Thus, it remains to be seen whether the use of MDM2-antagonists in clinical trials may exhibit similar effects. This concern enhances the need for highly specific agents.

Another critical factor to consider is the limited efficacy of p53-based cancer therapies in cells lacking the ability to phosphorylate p53Ser46, which subsequently increases the affinity of p53 to pro-apoptotic genes [150]. $\mathrm{Ma}$ et al. determined that neither nutlin-3, nor RITA were able to induce p53-mediated apoptosis in cancer cells that are unable to phosphorylate p53Ser46 [150]. Therefore, dysregulation of phosphorylation in those cancer cells might be a predicting factor of failed response to therapy.

\section{SMALL MOLECULES IN CLINICAL DEVELOPMENT}

Although some mut-p53 activators as well as MDM2-antagonists have shown potent activity in vitro, only a few compounds demonstrated desirable pharmacokinetic properties and tolerable toxicity profiles in vivo. Thus, the number of compounds in clinical trials remains relatively few. Among the best known inhibitors are cis-imidazolines, such as nutlins and spirooxindoles [16]. Table 10 gives an overview of some important small molecules targeting the p53 pathway that have entered clinical trials.

\section{CONCLUSIONS}

Cancer is a complex conglomeration of diseases. Elucidating the mechanisms of cancer remains elusive. This necessitates the search for novel strategies to overcome the challenge. Mutated p53 is not only a key player in carcinogenesis, but is also associated with resistance to established cytotoxic anticancer drugs such as cisplatin, epirubicin, 5-fluorouracil, methotrexate and 
Table 10: Some important p53 activators in clinical trials [https://clinicaltrials.gov/]

\begin{tabular}{|l|l|l|l|}
\hline Compound & Mechanism of action & Status & ClinicalTrials.gov identifiers \\
\hline PRIMA-1 $^{\text {Met }}$ (APR-246) & $\begin{array}{l}\text { Small molecule; mut-p53 } \\
\text { reactivator }\end{array}$ & $\begin{array}{l}\text { Phase I in hematological an prostatic } \\
\text { neoplasms (completed) }\end{array}$ & NCT00900614 \\
\hline PRIMA-1 $^{\text {Met }}$ (APR-246) & $\begin{array}{l}\text { Small molecule; mut-p53 } \\
\text { reactivator }\end{array}$ & $\begin{array}{l}\text { Phase Ib/I in ovarian cancer with } \\
\text { carboplatin/PLD (recruiting) }\end{array}$ & NCT02098343 \\
\hline RO5045337 (RG7112) & $\begin{array}{l}\text { Small molecule; MDM2 } \\
\text { antagonist }\end{array}$ & $\begin{array}{l}\text { Phase I in advanced solid tumours, solid } \\
\text { tumours, haematological neoplasms and } \\
\text { liposarcomas (all completed) }\end{array}$ & $\begin{array}{l}\text { NCT00559533 NCT01164033 } \\
\text { NCT }\end{array}$ \\
\hline RO5045337 (RG7112) & $\begin{array}{l}\text { Small molecule; MDM2 } \\
\text { antagonist }\end{array}$ & $\begin{array}{l}\text { Phase I in AML with cytarabine } \\
\text { (completed) }\end{array}$ & NCT01635296 \\
\hline RO5045337 (RG7112) & $\begin{array}{l}\text { Small molecule; MDM2 } \\
\text { antagonist }\end{array}$ & $\begin{array}{l}\text { Phase I in soft tissue sarcoma with } \\
\text { doxorubicin (completed) }\end{array}$ & NCT01605526 \\
\hline $\begin{array}{l}\text { RO5503781 } \\
\text { (RG7388) }\end{array}$ & $\begin{array}{l}\text { Small molecule; MDM2 } \\
\text { antagonist }\end{array}$ & $\begin{array}{l}\text { Phase I in AML as single agent or with } \\
\text { cytarabine (active, not recruiting) }\end{array}$ & NCT01773408 \\
\hline $\begin{array}{l}\text { RO5503781 } \\
\text { (RG7388) }\end{array}$ & $\begin{array}{l}\text { Small molecule; MDM2 } \\
\text { antagonist }\end{array}$ & $\begin{array}{l}\text { Phase I in advanced malignancies except } \\
\text { leukemia (completed) }\end{array}$ & NCT01462175 \\
\hline SAR405838 (MI-77301) & $\begin{array}{l}\text { Small molecule; MDM2 } \\
\text { antagonist }\end{array}$ & $\begin{array}{l}\text { Phase I in malignant neoplasms (active, } \\
\text { not recruiting) }\end{array}$ & NCT01636479 \\
\hline SAR405838 (MI-77301) & $\begin{array}{l}\text { Small molecule; MDM2 } \\
\text { antagonist }\end{array}$ & $\begin{array}{l}\text { Phase I in malignant neoplasms with } \\
\text { pimasertib (recruiting) }\end{array}$ & NCT01985191 \\
\hline
\end{tabular}

PLD, Pegylated Liposomal Doxorubicin Hydrochloride

AML, Acute Myelogenous Leukemia

many other chemotherapeutics. However, contradictory reports pertaining to different aspects of p53's actions prevent from devising fool-proof intervention strategies. For example, while some studies confirmed strong connections between p53 mutations and drug resistance, others did not. Methodological differences may at least in part account for the diverging results in the literature. Several reasons may contribute to these discrepancies, e.g. non-standardized methods for p53 status evaluation, differences concerning patient selection, different polychemotherapy regimens, duration of follow-up, etc. Thus, the general prognostic status and role of $\mathrm{p} 53$, though mainly positively confirmed, remains controversial to some extent. Due to the high frequency of p53 mutations in human tumors, this tumor suppressor is an important target for novel anticancer therapies. Several research teams have dealt with the possibilities of restoring p53's function to treat cancer and their efforts showed worthwhile outcomes. Many novel molecules have been identified so far to restore p53's wild-type conformation and thereby recover its tumor suppressive function. The results were also promising regarding the combination of small molecules with conventional anticancer drugs. For example, synergistic effects between PRIMA-1/APR246 and cisplatin have been shown in vivo and in vitro. However, further studies are required to develop specific small molecules with good pharmacokinetic profiles and acceptable tolerability in patients. Despite the fact that p53 mutations promote tumorigenesis, other mechanisms have also to be kept in mind. Among mechanisms concerning modifications in the pro- and antiapoptotic balance, even mechanisms involving drug uptake or export, changes molecular targets or DNA repair as well as mechanisms concerning the metabolic prodrug activation or drug inactivation are possible mechanisms causing drug resistance [151]. The fact that one half of all cancers express wt-p53 suggests the importance of investigating other members of the p53 pathway. Recently, small molecules capable of switching off the activity of MDM2, is a negative regulator of $\mathrm{p} 53$, have been identified. Novel MDM2 inhibitors increased the activity of combination treatment with standard chemotherapy. However, only few compounds possess desirable pharmacokinetic properties and acceptable toxicity profiles and further investigations are urgently needed.

In the future, combination therapies consisting of standard cytotoxic drugs and novel small molecules targeting p53 and MDM2 may be the key to fight cancer. Overcoming resistance to classical anticancer drugs by exploitation of synergistic effects of novel small molecules bears a huge potential to substantially improve the outcome of cancer chemotherapy. This goal is certainly not a trivial task, but is worth doing for the sake of alleviating the devastating consequences of the disease.

\section{CONFLICTS OF INTEREST}

The authors declare that they have no conflict of interest.

\section{REFERENCES}

1. Lane DP. Cancer. p53, guardian of the genome. Nature. 1992; 358(6381):15-16.

2. Wang $Z$ and Sun $Y$. Targeting p53 for Novel Anticancer Therapy. Transl Oncol. 2010; 3(1):1-12.

3. Lane D and Levine A. p53 Research: the past thirty years 
and the next thirty years. Cold Spring Harb Perspect Biol. 2010; 2(12):a000893.

4. Efeyan A and Serrano M. p53: guardian of the genome and policeman of the oncogenes. Cell Cycle. 2007; 6(9):10061010 .

5. Giaccia AJ and Kastan MB. The complexity of p53 modulation: emerging patterns from divergent signals. Genes Dev. 1998; 12(19):2973-2983.

6. Ko LJ and Prives C. p53: puzzle and paradigm. Genes Dev. 1996; 10(9):1054-1072.

7. Levine AJ. p53, the cellular gatekeeper for growth and division. Cell. 1997; 88(3):323-331.

8. D'Orazi G and Givol D. p53 reactivation: the link to zinc. Cell Cycle. 2012; 11(14):2581-2582.

9. Michael D and Oren M. The p53 and Mdm2 families in cancer. Curr Opin Genet Dev. 2002; 12(1):53-59.

10. Michael D and Oren M. The p53-Mdm2 module and the ubiquitin system. Semin Cancer Biol. 2003; 13(1):49-58.

11. Ashcroft M, Taya $Y$ and Vousden KH. Stress signals utilize multiple pathways to stabilize p53. Mol Cell Biol. 2000; 20(9):3224-3233.

12. Klein $\mathrm{C}$ and Vassilev LT. Targeting the p53-MDM2 interaction to treat cancer. Br J Cancer. 2004; 91(8):14151419.

13. Smith ND, Rubenstein JN, Eggener SE and Kozlowski JM. The p53 tumor suppressor gene and nuclear protein: basic science review and relevance in the management of bladder cancer. J Urol. 2003; 169(4):1219-1228.

14. Bargonetti J and Manfredi JJ. Multiple roles of the tumor suppressor p53. Curr Opin Oncol. 2002; 14(1):86-91.

15. Chiang MF, Chou PY, Wang WJ, Sze CI and Chang NS. Tumor Suppressor WWOX and p53 Alterations and Drug Resistance in Glioblastomas. Front Oncol. 2013; 3:43.

16. Bai L and Wang S. Targeting apoptosis pathways for new cancer therapeutics. Annu Rev Med. 2014; 65:139-155.

17. Vogelstein B, Lane D and Levine AJ. Surfing the p53 network. Nature. 2000; 408(6810):307-310.

18. Bai L and Zhu W. p53: structure, function and therapeutic application. J Cancer Mol. 2006; 2(4):141-153.

19. Hofseth LJ, Hussain SP and Harris CC. p53: 25 years after its discovery. Trends Pharmacol Sci. 2004; 25(4):177-181.

20. Khoury K and Domling A. P53 mdm2 inhibitors. Curr Pharm Des. 2012; 18(30):4668-4678.

21. Vousden KH and Lu X. Live or let die: the cell's response to p53. Nat Rev Cancer. 2002; 2(8):594-604.

22. Wang S, Zhao Y, Bernard D, Aguilar A and Kumar S. Targeting the MDM2-p53 Protein-Protein Interaction for New Cancer Therapeutics. Top Med Chem. 2012; 8:57-80.

23. Muller PA and Vousden KH. p53 mutations in cancer. Nat Cell Biol. 2013; 15(1):2-8.

24. Liu DP, Song $\mathrm{H}$ and $\mathrm{Xu} \mathrm{Y}$. A common gain of function of p53 cancer mutants in inducing genetic instability. Oncogene. 2010; 29(7):949-956.
25. Sigal A and Rotter V. Oncogenic mutations of the p53 tumor suppressor: the demons of the guardian of the genome. Cancer Res. 2000; 60(24):6788-6793.

26. Cho Y, Gorina S, Jeffrey PD and Pavletich NP. Crystal structure of a p53 tumor suppressor-DNA complex: understanding tumorigenic mutations. Science. 1994; 265(5170):346-355.

27. Wang $\mathrm{W}$, Zhu X, Zheng L, Zhu H and Y. H. Identification of novel inhibitors of p53-MDM2 interaction facilitated by pharmacophore-based virtual screening combining molecular docking strategy. Med Chem Commun. 2013; 4:411-416.

28. Lahav G, Rosenfeld N, Sigal A, Geva-Zatorsky N, Levine AJ, Elowitz MB and Alon U. Dynamics of the p53Mdm2 feedback loop in individual cells. Nat Genet. 2004; 36(2):147-150.

29. Momand J, Wu HH and Dasgupta G. MDM2--master regulator of the p53 tumor suppressor protein. Gene. 2000; 242(1-2):15-29.

30. Lakin ND and Jackson SP. Regulation of p53 in response to DNA damage. Oncogene. 1999; 18(53):7644-7655.

31. Piette J, Neel H and Marechal V. Mdm2: keeping p53 under control. Oncogene. 1997; 15(9):1001-1010.

32. Momand J, Jung D, Wilczynski S and Niland J. The MDM2 gene amplification database. Nucleic Acids Res. 1998; 26(15):3453-3459.

33. Bond GL, Hu W, Bond EE, Robins H, Lutzker SG, Arva NC, Bargonetti J, Bartel F, Taubert H, Wuerl P, Onel K, Yip L, Hwang SJ, Strong LC, Lozano G and Levine AJ. A single nucleotide polymorphism in the MDM2 promoter attenuates the p53 tumor suppressor pathway and accelerates tumor formation in humans. Cell. 2004; 119(5):591-602.

34. Geisler S, Borresen-Dale AL, Johnsen H, Aas T, Geisler J, Akslen LA, Anker G and Lonning PE. TP53 gene mutations predict the response to neoadjuvant treatment with 5-fluorouracil and mitomycin in locally advanced breast cancer. Clin Cancer Res. 2003; 9(15):5582-5588.

35. Marin JJ, Romero MR, Martinez-Becerra P, Herraez E and Briz O. Overview of the molecular bases of resistance to chemotherapy in liver and gastrointestinal tumours. Curr Mol Med. 2009; 9(9):1108-1129.

36. Huang $\mathrm{Y}$ and Sadee W. Membrane transporters and channels in chemoresistance and -sensitivity of tumor cells. Cancer Lett. 2006; 239(2):168-182.

37. Okabe M, Szakacs G, Reimers MA, Suzuki T, Hall MD, Abe T, Weinstein JN and Gottesman MM. Profiling SLCO and SLC22 genes in the NCI-60 cancer cell lines to identify drug uptake transporters. Mol Cancer Ther. 2008; 7(9):3081-3091.

38. Thiebaut F, Tsuruo T, Hamada H, Gottesman MM, Pastan I and Willingham MC. Cellular localization of the multidrugresistance gene product P-glycoprotein in normal human tissues. Proc Natl Acad Sci U S A. 1987; 84(21):7735-7738. 
39. Martinez C, Garcia-Martin E, Pizarro RM, Garcia-Gamito FJ and Agundez JA. Expression of paclitaxel-inactivating CYP3A activity in human colorectal cancer: implications for drug therapy. Br J Cancer. 2002; 87(6):681-686.

40. Pavillard V, Agostini C, Richard S, Charasson V, Montaudon D and Robert J. Determinants of the cytotoxicity of irinotecan in two human colorectal tumor cell lines. Cancer Chemother Pharmacol. 2002; 49(4):329335 .

41. Reardon JT, Vaisman A, Chaney SG and Sancar A. Efficient nucleotide excision repair of cisplatin, oxaliplatin, and Bisaceto-ammine-dichloro-cyclohexylamine-platinum(IV) (JM216) platinum intrastrand DNA diadducts. Cancer Res. 1999; 59(16):3968-3971.

42. Lin X, Kim HK and Howell SB. The role of DNA mismatch repair in cisplatin mutagenicity. J Inorg Biochem. 1999; 77(1-2):89-93.

43. Gourdier I, Del Rio M, Crabbe L, Candeil L, Copois V, Ychou M, Auffray C, Martineau P, Mechti N, Pommier $\mathrm{Y}$ and Pau B. Drug specific resistance to oxaliplatin is associated with apoptosis defect in a cellular model of colon carcinoma. FEBS Lett. 2002; 529(2-3):232-236.

44. Bunz F, Hwang PM, Torrance C, Waldman T, Zhang Y, Dillehay L, Williams J, Lengauer C, Kinzler KW and Vogelstein B. Disruption of p53 in human cancer cells alters the responses to therapeutic agents. J Clin Invest. 1999; 104(3):263-269.

45. O'Connor PM, Jackman J, Bae I, Myers TG, Fan S, Mutoh M, Scudiero DA, Monks A, Sausville EA, Weinstein JN, Friend S, Fornace AJ, Jr. and Kohn KW. Characterization of the p53 tumor suppressor pathway in cell lines of the National Cancer Institute anticancer drug screen and correlations with the growth-inhibitory potency of 123 anticancer agents. Cancer Res. 1997; 57(19):4285-4300.

46. Lin $X$ and Howell SB. DNA mismatch repair and $p 53$ function are major determinants of the rate of development of cisplatin resistance. Mol Cancer Ther. 2006; 5(5):12391247.

47. Gadducci A, Cosio S, Muraca S and Genazzani AR. Molecular mechanisms of apoptosis and chemosensitivity to platinum and paclitaxel in ovarian cancer: biological data and clinical implications. Eur J Gynaecol Oncol. 2002; 23(5):390-396.

48. Tung MC, Lin PL, Wang YC, He TY, Lee MC, Yeh SD, Chen CY and Lee H. Mutant p53 confers chemoresistance in non-small cell lung cancer by upregulating Nrf2. Oncotarget. 2015; 6:41692-41705. doi: 10.18632/ oncotarget.6150.

49. Ma Q. Role of nrf2 in oxidative stress and toxicity. Annu Rev Pharmacol Toxicol. 2013; 53:401-426.

50. Rusch V, Klimstra D, Venkatraman E, Oliver J, Martini N, Gralla R, Kris M and Dmitrovsky E. Aberrant p53 expression predicts clinical resistance to cisplatin-based chemotherapy in locally advanced non-small cell lung cancer. Cancer Res. 1995; 55(21):5038-5042.

51. Wang X, Chen JX, Liu YH, You C and Mao Q. Mutant TP53 enhances the resistance of glioblastoma cells to temozolomide by up-regulating $\mathrm{O}(6)$-methylguanine DNAmethyltransferase. Neurol Sci. 2013; 34(8):1421-1428.

52. Hermisson M, Klumpp A, Wick W, Wischhusen J, Nagel G, Roos W, Kaina B and Weller M. O6-methylguanine DNA methyltransferase and p53 status predict temozolomide sensitivity in human malignant glioma cells. J Neurochem. 2006; 96(3):766-776.

53. Hegi ME, Diserens AC, Gorlia T, Hamou MF, de Tribolet N, Weller M, Kros JM, Hainfellner JA, Mason W, Mariani L, Bromberg JE, Hau P, Mirimanoff RO, Cairncross JG, Janzer RC and Stupp R. MGMT gene silencing and benefit from temozolomide in glioblastoma. N Engl J Med. 2005; 352(10):997-1003.

54. Natsume A, Wakabayashi T, Ishii D, Maruta H, Fujii M, Shimato S, Ito M and Yoshida J. A combination of IFNbeta and temozolomide in human glioma xenograft models: implication of p53-mediated MGMT downregulation. Cancer Chemother Pharmacol. 2008; 61(4):653-659.

55. Zhang J, Stevens MF and Bradshaw TD. Temozolomide: mechanisms of action, repair and resistance. Curr Mol Pharmacol. 2012; 5(1):102-114.

56. Blough MD, Beauchamp DC, Westgate MR, Kelly JJ and Cairncross JG. Effect of aberrant p53 function on temozolomide sensitivity of glioma cell lines and brain tumor initiating cells from glioblastoma. J Neurooncol. 2011; 102(1):1-7.

57. Aas T, Borresen AL, Geisler S, Smith-Sorensen B, Johnsen $\mathrm{H}$, Varhaug JE, Akslen LA and Lonning PE. Specific P53 mutations are associated with de novo resistance to doxorubicin in breast cancer patients. Nat Med. 1996; 2(7):811-814.

58. Knappskog S, Chrisanthar R, Lokkevik E, Anker G, Ostenstad B, Lundgren S, Risberg T, Mjaaland I, Leirvaag $\mathrm{B}$, Miletic $\mathrm{H}$ and Lonning PE. Low expression levels of ATM may substitute for CHEK2 /TP53 mutations predicting resistance towards anthracycline and mitomycin chemotherapy in breast cancer. Breast Cancer Res. 2012; 14(2):R47.

59. Geisler S, Lonning PE, Aas T, Johnsen H, Fluge O, Haugen DF, Lillehaug JR, Akslen LA and Borresen-Dale AL. Influence of TP53 gene alterations and c-erbB-2 expression on the response to treatment with doxorubicin in locally advanced breast cancer. Cancer Res. 2001; 61(6):25052512.

60. Varna M, Bousquet G, Plassa LF, Bertheau P and Janin A. TP53 status and response to treatment in breast cancers. J Biomed Biotechnol. 2011; 2011:284584.

61. Bergamaschi D, Gasco M, Hiller L, Sullivan A, Syed N, Trigiante G, Yulug I, Merlano M, Numico G, Comino 
A, Attard M, Reelfs O, Gusterson B, Bell AK, Heath V, Tavassoli M, et al. p53 polymorphism influences response in cancer chemotherapy via modulation of p73-dependent apoptosis. Cancer Cell. 2003; 3(4):387-402.

62. Minotti G, Menna P, Salvatorelli E, Cairo G and Gianni L. Anthracyclines: molecular advances and pharmacologic developments in antitumor activity and cardiotoxicity. Pharmacol Rev. 2004; 56(2):185-229.

63. Fiorini C, Cordani M, Padroni C, Blandino G, Di Agostino $\mathrm{S}$ and Donadelli M. Mutant p53 stimulates chemoresistance of pancreatic adenocarcinoma cells to gemcitabine. Biochim Biophys Acta. 2015; 1853(1):89-100.

64. Galmarini CM, Clarke ML, Falette N, Puisieux A, Mackey JR and Dumontet C. Expression of a non-functional p53 affects the sensitivity of cancer cells to gemcitabine. Int $\mathrm{J}$ Cancer. 2002; 97(4):439-445.

65. Dhayat SA, Mardin WA, Seggewiss J, Strose AJ, Matuszcak C, Hummel R, Senninger N, Mees ST and Haier J. MicroRNA Profiling Implies New Markers of Gemcitabine Chemoresistance in Mutant p53 Pancreatic Ductal Adenocarcinoma. PLoS One. 2015; 10(11):e0143755.

66. Fuchs-Young R, Shirley SH, Lambertz I, Colby JK, Tian J, Johnston D, Gimenez-Conti IB, Donehower LA, Conti CJ and Hursting SD. P53 genotype as a determinant of ER expression and tamoxifen response in the MMTV-Wnt-1 model of mammary carcinogenesis. Breast Cancer Res Treat. 2011; 130(2):399-408.

67. Berger C, Qian Y and Chen X. The p53-estrogen receptor loop in cancer. Curr Mol Med. 2013; 13(8):1229-1240.

68. Katzenellenbogen BS, Choi I, Delage-Mourroux R, Ediger TR, Martini PG, Montano M, Sun J, Weis K and Katzenellenbogen JA. Molecular mechanisms of estrogen action: selective ligands and receptor pharmacology. J Steroid Biochem Mol Biol. 2000; 74(5):279-285.

69. Katzenellenbogen BS, Montano MM, Ekena K, Herman ME and McInerney EM. William L. McGuire Memorial Lecture. Antiestrogens: mechanisms of action and resistance in breast cancer. Breast Cancer Res Treat. 1997; 44(1):23-38.

70. Shang $\mathrm{Y}$ and Brown M. Molecular determinants for the tissue specificity of SERMs. Science. 2002; 295(5564):2465-2468.

71. Liu W, Konduri SD, Bansal S, Nayak BK, Rajasekaran SA, Karuppayil SM, Rajasekaran AK and Das GM. Estrogen receptor-alpha binds p53 tumor suppressor protein directly and represses its function. J Biol Chem. 2006; 281(15):9837-9840.

72. Huang S, Benavente S, Armstrong EA, Li C, Wheeler DL and Harari PM. p53 modulates acquired resistance to EGFR inhibitors and radiation. Cancer Res. 2011; 71(22):70717079 .

73. Huether A, Hopfner M, Baradari V, Schuppan D and Scherubl H. EGFR blockade by cetuximab alone or as combination therapy for growth control of hepatocellular cancer. Biochem Pharmacol. 2005; 70(11):1568-1578.

74. Sauer L, Gitenay D, Vo C and Baron VT. Mutant p53 initiates a feedback loop that involves Egr-1/EGF receptor/ ERK in prostate cancer cells. Oncogene. 2010; 29(18):26282637.

75. Hafsi $\mathrm{H}$ and Hainaut P. Pharmacological rescue of $\mathrm{p} 53$ in cancer cells: the soloist meets the PRIMA donna. Cell Cycle. 2011; 10(6):875-876.

76. Bykov VJ, Issaeva N, Zache N, Shilov A, Hultcrantz M, Bergman J, Selivanova G and Wiman KG. Reactivation of mutant $\mathrm{p} 53$ and induction of apoptosis in human tumor cells by maleimide analogs. J Biol Chem. 2005; 280(34):3038430391 .

77. Issaeva N, Bozko P, Enge M, Protopopova M, Verhoef LG, Masucci M, Pramanik A and Selivanova G. Small molecule RITA binds to p53, blocks p53-HDM-2 interaction and activates p53 function in tumors. Nat Med. 2004; 10(12):1321-1328.

78. Bykov VJ and Wiman KG. Mutant p53 reactivation by small molecules makes its way to the clinic. FEBS Lett. 2014; 588(16):2622-2627.

79. Yu X, Vazquez A, Levine AJ and Carpizo DR. Allelespecific p53 mutant reactivation. Cancer Cell. 2012; 21(5):614-625.

80. Boeckler FM, Joerger AC, Jaggi G, Rutherford TJ, Veprintsev DB and Fersht AR. Targeted rescue of a destabilized mutant of p53 by an in silico screened drug. Proc Natl Acad Sci U S A. 2008; 105(30):10360-10365.

81. Rauf SM, Endou A, Takaba H and Miyamoto A. Effect of Y220C mutation on p53 and its rescue mechanism: a computer chemistry approach. Protein J. 2013; 32(1):68-74.

82. Yu Y, Kalinowski DS, Kovacevic Z, Siafakas AR, Jansson PJ, Stefani C, Lovejoy DB, Sharpe PC, Bernhardt PV and Richardson DR. Thiosemicarbazones from the old to new: iron chelators that are more than just ribonucleotide reductase inhibitors. J Med Chem. 2009; 52(17):5271-5294.

83. Hainaut $\mathrm{P}$ and Milner J. A structural role for metal ions in the "wild-type" conformation of the tumor suppressor protein p53. Cancer Res. 1993; 53(8):1739-1742.

84. http://p53.iarc.fr.

85. Joerger AC and Fersht AR. Structural biology of the tumor suppressor p53. Annu Rev Biochem. 2008; 77:557-582.

86. Petitjean A, Mathe E, Kato S, Ishioka C, Tavtigian SV, Hainaut $P$ and Olivier M. Impact of mutant p53 functional properties on TP53 mutation patterns and tumor phenotype: lessons from recent developments in the IARC TP53 database. Hum Mutat. 2007; 28(6):622-629.

87. Joerger AC, Ang HC and Fersht AR. Structural basis for understanding oncogenic p53 mutations and designing rescue drugs. Proc Natl Acad Sci U S A. 2006; 103(41):15056-15061.

88. Wiman KG. Pharmacological reactivation of mutant $\mathrm{p} 53$ : 
from protein structure to the cancer patient. Oncogene. 2010; 29(30):4245-4252.

89. Lambert JM, Gorzov P, Veprintsev DB, Soderqvist M, Segerback D, Bergman J, Fersht AR, Hainaut P, Wiman KG and Bykov VJ. PRIMA-1 reactivates mutant p53 by covalent binding to the core domain. Cancer Cell. 2009; 15(5):376-388.

90. Sun XZ, Vinci C, Makmura L, Han S, Tran D, Nguyen J, Hamann M, Grazziani S, Sheppard S, Gutova M, Zhou F, Thomas J and Momand J. Formation of disulfide bond in 553 correlates with inhibition of DNA binding and tetramerization. Antioxid Redox Signal. 2003; 5(5):655665 .

91. Li XL, Zhou J, Chan ZL, Chooi JY, Chen ZR and Chng WJ. PRIMA-1met (APR-246) inhibits growth of colorectal cancer cells with different p53 status through distinct mechanisms. Oncotarget. 2015; 6:36689-36699. doi: 10.18632/oncotarget.5385.

92. Zhao CY, Grinkevich VV, Nikulenkov F, Bao W and Selivanova G. Rescue of the apoptotic-inducing function of mutant p53 by small molecule RITA. Cell Cycle. 2010; 9(9):1847-1855.

93. Bykov VJ, Issaeva N, Shilov A, Hultcrantz M, Pugacheva E, Chumakov P, Bergman J, Wiman KG and Selivanova G. Restoration of the tumor suppressor function to mutant p53 by a low-molecular-weight compound. Nat Med. 2002; 8(3):282-288.

94. Saha MN, Chen Y, Chen MH, Chen G and Chang H. Small molecule MIRA-1 induces in vitro and in vivo antimyeloma activity and synergizes with current anti-myeloma agents. Br J Cancer. 2014; 110(9):2224-2231.

95. Gomez-Lazaro M, Galindo MF, Concannon CG, Segura MF, Fernandez-Gomez FJ, Llecha N, Comella JX, Prehn JH and Jordan J. 6-Hydroxydopamine activates the mitochondrial apoptosis pathway through p38 MAPKmediated, p53-independent activation of Bax and PUMA. J Neurochem. 2008; 104(6):1599-1612.

96. Jiang CC, Lucas K, Avery-Kiejda KA, Wade M, deBock CE, Thorne RF, Allen J, Hersey P and Zhang XD. Upregulation of Mcl-1 is critical for survival of human melanoma cells upon endoplasmic reticulum stress. Cancer Res. 2008; 68(16):6708-6717.

97. Kussie PH, Gorina S, Marechal V, Elenbaas B, Moreau J, Levine AJ and Pavletich NP. Structure of the MDM2 oncoprotein bound to the p53 tumor suppressor transactivation domain. Science. 1996; 274(5289):948-953.

98. Deng CX. SIRT1, is it a tumor promoter or tumor suppressor? Int J Biol Sci. 2009; 5(2):147-152.

99. Sriraman A, Radovanovic M, Wienken M, Najafova Z, Li $\mathrm{Y}$ and Dobbelstein M. Cooperation of Nutlin-3a and a Wip1 inhibitor to induce p53 activity. Oncotarget. 2016; 7:3162331638. doi: 10.18632/oncotarget.9302.

100. Solomon JM, Pasupuleti R, Xu L, McDonagh T, Curtis R, DiStefano PS and Huber LJ. Inhibition of SIRT1 catalytic activity increases p53 acetylation but does not alter cell survival following DNA damage. Mol Cell Biol. 2006; 26(1):28-38.

101. Pechackova S, Burdova K, Benada J, Kleiblova P, Jenikova $\mathrm{G}$ and Macurek L. Inhibition of WIP1 phosphatase sensitizes breast cancer cells to genotoxic stress and to MDM2 antagonist nutlin-3. Oncotarget. 2016; 7:1445814475. doi: 10.18632/oncotarget. 7363 .

102. Esfandiari A, Hawthorne TA, Nakjang S and Lunec J. Chemical Inhibition of Wild-Type p53-Induced Phosphatase 1 (WIP1/PPM1D) by GSK2830371 Potentiates the Sensitivity to MDM2 Inhibitors in a p53-Dependent Manner. Mol Cancer Ther. 2016; 15(3):379-391.

103. Tovar C, Graves B, Packman K, Filipovic Z, Higgins B, Xia M, Tardell C, Garrido R, Lee E, Kolinsky K, To KH, Linn M, Podlaski F, Wovkulich P, Vu B and Vassilev LT. MDM2 small-molecule antagonist RG7112 activates p53 signaling and regresses human tumors in preclinical cancer models. Cancer Res. 2013; 73(8):2587-2597.

104. Ding Q, Zhang Z, Liu JJ, Jiang N, Zhang J, Ross TM, Chu XJ, Bartkovitz D, Podlaski F, Janson C, Tovar C, Filipovic ZM, Higgins B, Glenn K, Packman K, Vassilev LT, et al. Discovery of RG7388, a potent and selective p53-MDM2 inhibitor in clinical development. J Med Chem. 2013; 56(14):5979-5983.

105. Sosin AM, Burger AM, Siddiqi A, Abrams J, Mohammad RM and Al-Katib AM. HDM2 antagonist MI-219 (spirooxindole), but not Nutlin-3 (cis-imidazoline), regulates p53 through enhanced HDM2 autoubiquitination and degradation in human malignant B-cell lymphomas. J Hematol Oncol. 2012; 5:57.

106. Patel S and Player MR. Small-molecule inhibitors of the p53-HDM2 interaction for the treatment of cancer. Expert Opin Investig Drugs. 2008; 17(12):1865-1882.

107. Wang S, Sun W, Zhao Y, McEachern D, Meaux I, Barriere C, Stuckey JA, Meagher JL, Bai L, Liu L, Hoffman-Luca CG, Lu J, Shangary S, Yu S, Bernard D, Aguilar A, et al. SAR405838: an optimized inhibitor of MDM2-p53 interaction that induces complete and durable tumor regression. Cancer Res. 2014; 74(20):5855-5865.

108. Burmakin M, Shi Y, Hedstrom E, Kogner P and Selivanova G. Dual targeting of wild-type and mutant p53 by small molecule RITA results in the inhibition of N-Myc and key survival oncogenes and kills neuroblastoma cells in vivo and in vitro. Clin Cancer Res. 2013; 19(18):5092-5103.

109. Guo Z, Zhuang C, Zhu L, Zhang Y, Yao J, Dong G, Wang S, Liu Y, Chen H, Sheng C, Miao Z and Zhang W. Structure-activity relationship and antitumor activity of thio-benzodiazepines as p53-MDM2 protein-protein interaction inhibitors. Eur J Med Chem. 2012; 56:10-16.

110. Vassilev LT, Vu BT, Graves B, Carvajal D, Podlaski F, Filipovic Z, Kong N, Kammlott U, Lukacs C, Klein $\mathrm{C}$, Fotouhi $\mathrm{N}$ and Liu EA. In vivo activation of the p53 pathway by small-molecule antagonists of MDM2. Science. 2004; 303(5659):844-848. 
111. Tovar C, Rosinski J, Filipovic Z, Higgins B, Kolinsky K, Hilton H, Zhao X, Vu BT, Qing W, Packman K, Myklebost O, Heimbrook DC and Vassilev LT. Small-molecule MDM2 antagonists reveal aberrant p53 signaling in cancer: implications for therapy. Proc Natl Acad Sci U S A. 2006; 103(6):1888-1893.

112. Sun SH, Zheng M, Ding K, Wang S and Sun Y. A small molecule that disrupts Mdm2-p53 binding activates p53, induces apoptosis and sensitizes lung cancer cells to chemotherapy. Cancer Biol Ther. 2008; 7(6):845-852.

113. Zhao Y, Yu S, Sun W, Liu L, Lu J, McEachern D, Shargary S, Bernard D, Li X, Zhao T, Zou P, Sun D and Wang S. A potent small-molecule inhibitor of the MDM2-p53 interaction (MI-888) achieved complete and durable tumor regression in mice. J Med Chem. 2013; 56(13):5553-5561.

114. Supiot S, Hill RP and Bristow RG. Nutlin-3 radiosensitizes hypoxic prostate cancer cells independent of p53. Mol Cancer Ther. 2008; 7(4):993-999.

115. Cao C, Shinohara ET, Subhawong TK, Geng L, Kim KW, Albert JM, Hallahan DE and Lu B. Radiosensitization of lung cancer by nutlin, an inhibitor of murine double minute 2. Mol Cancer Ther. 2006; 5(2):411-417.

116. Coll-Mulet L, Iglesias-Serret D, Santidrian AF, Cosialls AM, de Frias M, Castano E, Campas C, Barragan M, de Sevilla AF, Domingo A, Vassilev LT, Pons G and Gil J. MDM2 antagonists activate p53 and synergize with genotoxic drugs in B-cell chronic lymphocytic leukemia cells. Blood. 2006; 107(10):4109-4114.

117. Kojima K, Konopleva M, McQueen T, O’Brien S, Plunkett W and Andreeff M. Mdm2 inhibitor Nutlin-3a induces p53-mediated apoptosis by transcription-dependent and transcription-independent mechanisms and may overcome Atm-mediated resistance to fludarabine in chronic lymphocytic leukemia. Blood. 2006; 108(3):993-1000.

118. Barbieri E, Mehta P, Chen Z, Zhang L, Slack A, Berg S and Shohet JM. MDM2 inhibition sensitizes neuroblastoma to chemotherapy-induced apoptotic cell death. Mol Cancer Ther. 2006; 5(9):2358-2365.

119. Wang W, Shangguan S, Qiu N, Hu C, Zhang L and Hu $\mathrm{Y}$. Design, synthesis and biological evaluation of novel 3,4,5-trisubstituted aminothiophenes as inhibitors of p53MDM2 interaction. Part 1. Bioorg Med Chem. 2013; 21(11):2879-2885.

120. Jiang M, Pabla N, Murphy RF, Yang T, Yin XM, Degenhardt K, White E and Dong Z. Nutlin-3 protects kidney cells during cisplatin therapy by suppressing Bax/ Bak activation. J Biol Chem. 2007; 282(4):2636-2645.

121. Xia M, Knezevic D, Tovar C, Huang B, Heimbrook DC and Vassilev LT. Elevated MDM2 boosts the apoptotic activity of p53-MDM2 binding inhibitors by facilitating MDMX degradation. Cell Cycle. 2008; 7(11):1604-1612.

122. Deben C, Wouters A, Op de Beeck K, van Den Bossche J, Jacobs J, Zwaenepoel K, Peeters M, Van Meerbeeck J, Lardon F, Rolfo C, Deschoolmeester V and Pauwels P.
The MDM2-inhibitor Nutlin-3 synergizes with cisplatin to induce p53 dependent tumor cell apoptosis in non-small cell lung cancer. Oncotarget. 2015; 6:22666-22679. doi: 10.18632/oncotarget.4433.

123. Wang B, Fang L, Zhao H, Xiang T and Wang D. MDM2 inhibitor Nutlin-3a suppresses proliferation and promotes apoptosis in osteosarcoma cells. Acta Biochim Biophys Sin (Shanghai). 2012; 44(8):685-691.

124. Tonsing-Carter E, Bailey BJ, Saadatzadeh MR, Ding J, Wang H, Sinn AL, Peterman KM, Spragins TK, Silver JM, Sprouse AA, Georgiadis TM, Gunter TZ, Long EC, Minto RE, Marchal CC, Batuello CN, et al. Potentiation of Carboplatin-Mediated DNA Damage by the Mdm2 Modulator Nutlin-3a in a Humanized Orthotopic Breastto-Lung Metastatic Model. Mol Cancer Ther. 2015; 14(12):2850-2863.

125. Schnitt SJ. Classification and prognosis of invasive breast cancer: from morphology to molecular taxonomy. Mod Pathol. 2010; 23 Suppl 2:S60-64.

126. Dent R, Trudeau M, Pritchard KI, Hanna WM, Kahn HK, Sawka CA, Lickley LA, Rawlinson E, Sun P and Narod SA. Triple-negative breast cancer: clinical features and patterns of recurrence. Clin Cancer Res. 2007; 13(15 Pt 1):44294434.

127. Ambrosini G, Sambol EB, Carvajal D, Vassilev LT, Singer $\mathrm{S}$ and Schwartz GK. Mouse double minute antagonist Nutlin-3a enhances chemotherapy-induced apoptosis in cancer cells with mutant p53 by activating E2F1. Oncogene. 2007; 26(24):3473-3481.

128. Lau LM, Nugent JK, Zhao $X$ and Irwin MS. HDM2 antagonist Nutlin-3 disrupts p73-HDM2 binding and enhances p73 function. Oncogene. 2008; 27(7):997-1003.

129. LaRusch GA, Jackson MW, Dunbar JD, Warren RS, Donner DB and Mayo LD. Nutlin3 blocks vascular endothelial growth factor induction by preventing the interaction between hypoxia inducible factor 1alpha and Hdm2. Cancer Res. 2007; 67(2):450-454.

130. Fuertes MA, Castilla J, Alonso C and Perez JM. Cisplatin biochemical mechanism of action: from cytotoxicity to induction of cell death through interconnections between apoptotic and necrotic pathways. Curr Med Chem. 2003; 10(3):257-266.

131. Leao M, Pereira C, Bisio A, Ciribilli Y, Paiva AM, Machado N, Palmeira A, Fernandes MX, Sousa E, Pinto M, Inga $A$ and Saraiva L. Discovery of a new small-molecule inhibitor of p53-MDM2 interaction using a yeast-based approach. Biochem Pharmacol. 2013; 85(9):1234-1245.

132. Grasberger BL, Lu T, Schubert C, Parks DJ, Carver TE, Koblish HK, Cummings MD, LaFrance LV, Milkiewicz KL, Calvo RR, Maguire D, Lattanze J, Franks CF, Zhao S, Ramachandren K, Bylebyl GR, et al. Discovery and cocrystal structure of benzodiazepinedione HDM2 antagonists that activate p53 in cells. J Med Chem. 2005; 48(4):909-912. 
133. Raboisson P, Marugan JJ, Schubert C, Koblish HK, Lu T, Zhao S, Player MR, Maroney AC, Reed RL, Huebert ND, Lattanze J, Parks DJ and Cummings MD. Structurebased design, synthesis, and biological evaluation of novel 1,4-diazepines as HDM2 antagonists. Bioorg Med Chem Lett. 2005; 15(7):1857-1861.

134. Parks DJ, Lafrance LV, Calvo RR, Milkiewicz KL, Gupta V, Lattanze J, Ramachandren K, Carver TE, Petrella EC, Cummings MD, Maguire D, Grasberger BL and Lu T. 1,4-Benzodiazepine-2,5-diones as small molecule antagonists of the HDM2-p53 interaction: discovery and SAR. Bioorg Med Chem Lett. 2005; 15(3):765-770.

135. Cummings MD, Schubert C, Parks DJ, Calvo RR, LaFrance LV, Lattanze J, Milkiewicz KL and Lu T. Substituted 1,4-benzodiazepine-2,5-diones as alpha-helix mimetic antagonists of the HDM2-p53 protein-protein interaction. Chem Biol Drug Des. 2006; 67(3):201-205.

136. Parks DJ, LaFrance LV, Calvo RR, Milkiewicz KL, Marugan JJ, Raboisson P, Schubert C, Koblish HK, Zhao $\mathrm{S}$, Franks CF, Lattanze J, Carver TE, Cummings MD, Maguire D, Grasberger BL, Maroney AC, et al. Enhanced pharmacokinetic properties of 1,4-benzodiazepine-2,5dione antagonists of the HDM2-p53 protein-protein interaction through structure-based drug design. Bioorg Med Chem Lett. 2006; 16(12):3310-3314.

137. Koblish HK, Zhao S, Franks CF, Donatelli RR, Tominovich RM, LaFrance LV, Leonard KA, Gushue JM, Parks DJ, Calvo RR, Milkiewicz KL, Marugan JJ, Raboisson $\mathrm{P}$, Cummings MD, Grasberger BL, Johnson DL, et al. Benzodiazepinedione inhibitors of the Hdm2:p53 complex suppress human tumor cell proliferation in vitro and sensitize tumors to doxorubicin in vivo. Mol Cancer Ther. 2006; 5(1):160-169.

138. Ding K, Lu Y, Nikolovska-Coleska Z, Wang G, Qiu S, Shangary S, Gao W, Qin D, Stuckey J, Krajewski K, Roller PP and Wang S. Structure-based design of spiro-oxindoles as potent, specific small-molecule inhibitors of the MDM2-p53 interaction. J Med Chem. 2006; 49(12):34323435 .

139. Samudio IJ, Duvvuri S, Clise-Dwyer K, Watt JC, Mak D, Kantarjian H, Yang D, Ruvolo V and Borthakur G. Activation of p53 signaling by MI-63 induces apoptosis in acute myeloid leukemia cells. Leuk Lymphoma. 2010; 51(5):911-919.

140. Nakamura Y, Kato H, Nishikawa T, Iwasaki N, Suwa Y, Rotinsulu H, Losung F, Maarisit W, Mangindaan RE, Morioka $\mathrm{H}$, Yokosawa $\mathrm{H}$ and Tsukamoto $\mathrm{S}$. Siladenoserinols A-L: new sulfonated serinol derivatives from a tunicate as inhibitors of p53-Hdm2 interaction. Org Lett. 2013; 15(2):322-325.

141. Bill KL, Garnett J, Meaux I, Ma X, Creighton CJ, Bolshakov S, Barriere C, Debussche L, Lazar AJ, Prudner BC, Casadei L, Braggio D, Lopez G, Zewdu A, Bid H, Lev D, et al. SAR405838: A Novel and Potent Inhibitor of the MDM2:p53 Axis for the Treatment of Dedifferentiated
Liposarcoma. Clin Cancer Res. 2016; 22(5):1150-1160.

142. Selivanova G. Therapeutic targeting of p53 by small molecules. Semin Cancer Biol. 2010; 20(1):46-56.

143. Grinkevich V. (2011). p53 reactivation by the small molecule RITA: molecular mechanism. In: Institutet K, ed. (Stockholm: Karolinska Institutet).

144. Weilbacher A, Gutekunst M, Oren M, Aulitzky WE and van der Kuip H. RITA can induce cell death in p53-defective cells independently of p53 function via activation of JNK/ SAPK and p38. Cell Death Dis. 2014; 5:e1318.

145. Aziz MH, Shen H and Maki CG. Acquisition of p53 mutations in response to the non-genotoxic p53 activator Nutlin-3. Oncogene. 2011; 30(46):4678-4686.

146. Castanheiro RA, Pinto MM, Silva AM, Cravo SM, Gales L, Damas AM, Nazareth N, Nascimento MS and Eaton G. Dihydroxyxanthones prenylated derivatives: synthesis, structure elucidation, and growth inhibitory activity on human tumor cell lines with improvement of selectivity for MCF-7. Bioorg Med Chem. 2007; 15(18):6080-6088.

147. Pinto MM, Sousa ME and Nascimento MS. Xanthone derivatives: new insights in biological activities. Curr Med Chem. 2005; 12(21):2517-2538.

148. Zhao Y, Bernard D and Wang S. Small Molecule Inhibitors of MDM2-p53 and MDMX-p53 Interactions as New Cancer Therapeutics. BioDiscovery Journal. 2013; 8:1-15.

149. Pedraza-Chaverri J, Cardenas-Rodriguez N, OrozcoIbarra $\mathrm{M}$ and Perez-Rojas JM. Medicinal properties of mangosteen (Garcinia mangostana). Food Chem Toxicol. 2008; 46(10):3227-3239.

150. Chantarasriwong O, Batova A, Chavasiri W and Theodorakis EA. Chemistry and biology of the caged Garcinia xanthones. Chemistry. 2010; 16(33):9944-9962.

151. Chitchumroonchokchai C, Thomas-Ahner JM, Li J, Riedl KM, Nontakham J, Suksumrarn S, Clinton SK, Kinghorn $\mathrm{AD}$ and Failla ML. Anti-tumorigenicity of dietary alphamangostin in an HT-29 colon cell xenograft model and the tissue distribution of xanthones and their phase II metabolites. Mol Nutr Food Res. 2013; 57(2):203-211.

152. Zhao J, Qi Q, Yang Y, Gu HY, Lu N, Liu W, Wang W, Qiang L, Zhang LB, You QD and Guo QL. Inhibition of alpha(4) integrin mediated adhesion was involved in the reduction of B16-F10 melanoma cells lung colonization in $\mathrm{C} 57 \mathrm{BL} / 6$ mice treated with gambogic acid. Eur $\mathrm{J}$ Pharmacol. 2008; 589(1-3):127-131.

153. Gu H, Wang X, Rao S, Wang J, Zhao J, Ren FL, Mu R, Yang Y, Qi Q, Liu W, Lu N, Ling H, You Q and Guo Q. Gambogic acid mediates apoptosis as a p53 inducer through down-regulation of $\mathrm{mdm} 2$ in wild-type p53-expressing cancer cells. Mol Cancer Ther. 2008; 7(10):3298-3305.

154. Shibata MA, Iinuma M, Morimoto J, Kurose H, Akamatsu $\mathrm{K}$, Okuno Y, Akao Y and Otsuki Y. alpha-Mangostin extracted from the pericarp of the mangosteen (Garcinia mangostana Linn) reduces tumor growth and lymph node metastasis in an immunocompetent xenograft model of 
metastatic mammary cancer carrying a p53 mutation. BMC Med. 2011; 9:69.

155. Warner WA, Sanchez R, Dawoodian A, Li E and Momand J. Identification of FDA-approved drugs that computationally bind to MDM2. Chem Biol Drug Des. 2012; 80(4):631-637.

156. Essmann F and Schulze-Osthoff K. Translational approaches targeting the p53 pathway for anti-cancer therapy. Br J Pharmacol. 2012; 165(2):328-344.

157. Ray-Coquard I, Blay JY, Italiano A, Le Cesne A, Penel N, Zhi J, Heil F, Rueger R, Graves B, Ding M, Geho D, Middleton SA, Vassilev LT, Nichols GL and Bui BN. Effect of the MDM2 antagonist RG7112 on the P53 pathway in patients with MDM2-amplified, well-differentiated or dedifferentiated liposarcoma: an exploratory proof-ofmechanism study. Lancet Oncol. 2012; 13(11):1133-1140.

158. Pellegrino M, Mancini F, Luca R, Coletti A, Giacche N, Manni I, Arisi I, Florenzano F, Teveroni E, Buttarelli M, Fici L, Brandi R, Bruno T, Fanciulli M, D’Onofrio M, Piaggio $\mathrm{G}$, et al. Targeting the MDM2/MDM4 interaction interface as a promising approach for $\mathrm{p} 53$ reactivation therapy. Cancer Res. 2015; 75(21):4560-4572.

159. Iancu-Rubin C, Mosoyan G, Glenn K, Gordon RE, Nichols GL and Hoffman R. Activation of p53 by the MDM2 inhibitor RG7112 impairs thrombopoiesis. Exp Hematol. 2014; 42(2):137-145 e135.
160. Yu X, Narayanan S, Vazquez A and Carpizo DR. Small molecule compounds targeting the p53 pathway: are we finally making progress? Apoptosis. 2014; 19(7):10551068.

161. Teoh PJ and Chng WJ. p53 abnormalities and potential therapeutic targeting in multiple myeloma. Biomed Res Int. 2014; 2014:717919.

162. Mirzayans R, Andrais B, Scott A and Murray D. New insights into p53 signaling and cancer cell response to DNA damage: implications for cancer therapy. J Biomed Biotechnol. 2012; 2012:170325.

163. Mendrysa SM, McElwee MK, Michalowski J, O'Leary KA, Young KM and Perry ME. mdm2 Is critical for inhibition of p53 during lymphopoiesis and the response to ionizing irradiation. Mol Cell Biol. 2003; 23(2):462-472.

164. Ma T, Yamada S, Ichwan SJ, Iseki S, Ohtani K, Otsu M and Ikeda MA. Inability of p53-reactivating compounds Nutlin-3 and RITA to overcome p53 resistance in tumor cells deficient in p53Ser46 phosphorylation. Biochem Biophys Res Commun. 2012; 417(3):931-937. 